\title{
Reactions of Malononitrile Dimer with Isothiocyanates
}

\author{
V. V. Dotsenko ${ }^{a, b, *}$, A. V. Bespalov ${ }^{a}$, A. A. Russkikh ${ }^{a}$, V. K. Kindop ${ }^{a}$, N. A. Aksenov ${ }^{b}$, \\ I. V. Aksenova ${ }^{b}$, S. V. Shcherbakov ${ }^{b}$, and S. N . Ovcharov ${ }^{b}$ \\ ${ }^{a}$ Kuban State University, Krasnodar, 350040 Russia \\ ${ }^{b}$ North Caucasus Federal University, Stavropol, 355009 Russia \\ *e-mail:victor_dotsenko_@mail.ru
}

Received April 19, 2021; revised April 19, 2021; accepted May 6, 2021

\begin{abstract}
The reaction of 2-amino-1,1,3-tricyanopropene (malononitrile dimer) with isothiocyanates leads to 1-substituted 4,6-diamino-2-thioxo-1,2-dihydropyridine-3,5-dicarbonitriles or 4,6-diamino-2-(phenylimino)-2Hthiopyran-3,5-dicarbonitrile, depending on the conditions. Quantum-chemical modeling of the IR spectra and reaction routes for the synthesized compounds was carried out. In silico predictive analysis of potential protein targets, compliance with bioavailability criteria, and ADMET parameters was performed.
\end{abstract}

Keywords: 2-amino-1,1,3-tricyanopropene, isothiocyanates, heterocyclization, $2 \mathrm{H}$-thiopyrans, 2-thioxopyridines, quantum chemical calculations

DOI: $10.1134 / \mathrm{S} 1070363221060013$

2-Amino-1,1,3-tricyanopropene $\mathbf{1}$, which is readily prepared by the dimerization of malononitrile [1], is a polyfunctional reagent widely used in synthetic organic chemistry. Heterocyclizations involving malononitrile dimer 1 are known since the middle of XX century and are fairly well studied (for reviews, see [2-4]). Nevertheless, there are contradictory data in the literature concerning the regioselectivity of the reactions of malononitrile dimer 1 with isothiocyanates. Thus, Eldin [5] described the reaction of dimer $\mathbf{1}$ with phenyl isothiocyanate in the presence of a base in DMF, leading to substituted pyridine 2 . The structure of the latter is also confirmed by its S-alkylation, for example, to thienopyridines $\mathbf{3}$ [6-8] (Scheme 1). At the same time, a similar reaction of dimer 1 with PhNCS in pyridine under reflux leads, according to [9], to substituted pyrimidine 4 . At the same time, it should be noted that the spectral data in $[5,9]$ do not allow one to unambiguously assign structures $\mathbf{2}$ or $\mathbf{4}$ to the products of these reactions.

Continuing research on the chemistry of malononitrile dimer [10-12], we decided to study in detail the regioselectivity of the heterocyclization of 2-amino-1,1,3tricyanopropene $\mathbf{1}$ with isothiocyanates and establish the real structure of the resulting compounds. Possible products 2 hold promise as starting reagents for the synthesis of thieno[2,3- $b]$ pyridine derivatives, many of which have pharmacologically useful properties [13-16]. On the other hand, compounds 2-4 are convenient and accessible substrates for preparing S, N-polyheterocyclic assemblies by the Mannich reaction (see, for example, [17-21]).

We reproduced the procedure in [5] to obtain, in a yield of $74 \%$, a product that actually has (according to the IR and NMR spectra) the structure of 4,6-diamino-2thioxo-1-phenyl-1,2-dihydropyridine-3,5-dicarbonitrile 2 (Table 1, entry 1; Scheme 2). Further studies showed that the reaction of PhNCS with dimer 1, in principle, does not require harsh conditions similar to those in [5]. For example, pyridine 2 was obtained in $84-92 \%$ yields by the reaction of dimer $\mathbf{1}$ with phenyl isothiocyanate at room temperature in $\mathrm{EtOH}$ in the presence of $\mathrm{Et}_{3} \mathrm{~N}$ (Table 1, entry 2). A similar reaction with allyl isothiocyanate gives 1-allyl-4,6-diamino-2-thioxo-1,2dihydropyridine-3,5-dicarbonitrile 5 in $58-73 \%$ yields (Table 1, entry 6; Scheme 2). The use of stronger bases did not show obvious advantages. For example, the reaction of dimer 1 with allyl isothiocyanate in a superbasic medium ( $\mathrm{KOH}$ in DMSO), too, leads to the isolation of compound 5 in a yield of $71 \%$ (Table 1, entry 7), but the resulting product requires additional purification. Compound $\mathbf{2}$ is a 


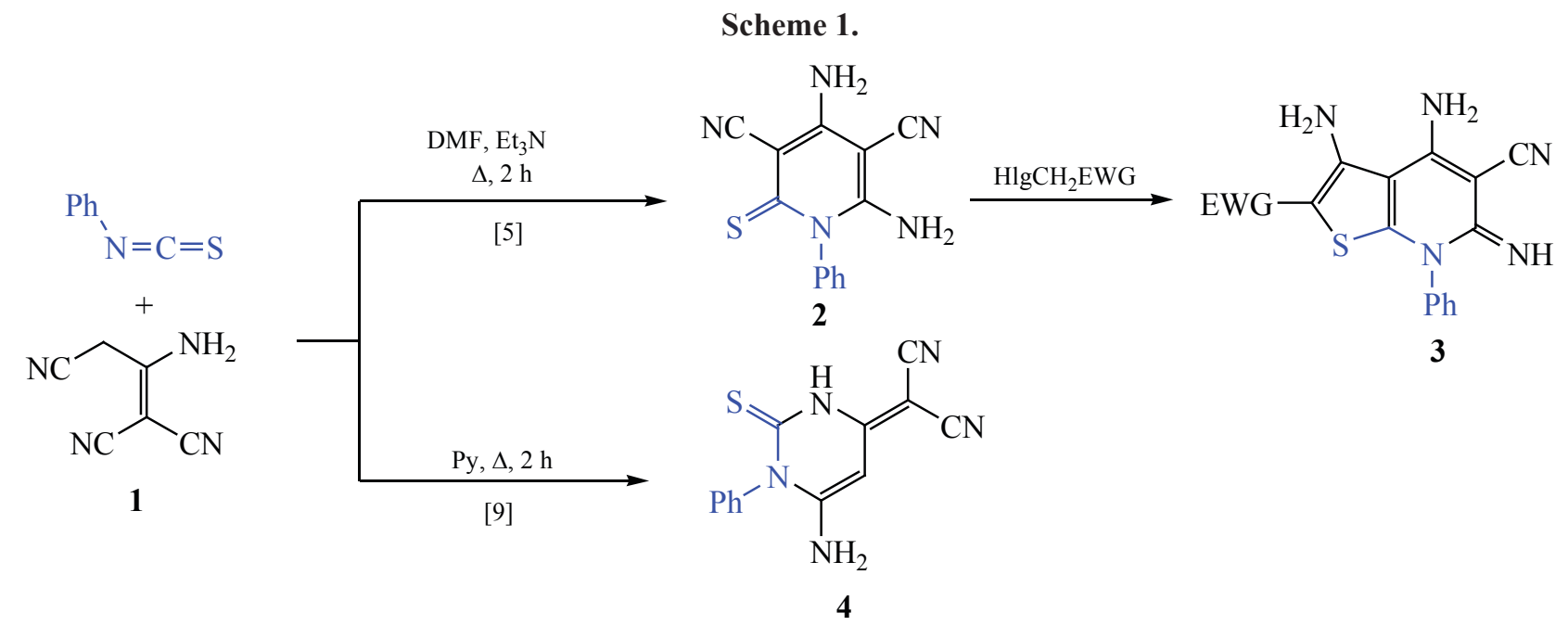

yellow powder insoluble in water and $\mathrm{EtOH}$, moderately soluble in acetone or in an AcOH-DMF mixture under heating. Compound $\mathbf{5}$ forms colorless crystals soluble in acetone and hot $\mathrm{EtOH}$. The results of all experiments are summarized in Table 1.

Reproducing the method of synthesis of pyrimidine 4, described by Abdel-Latif et al. [9], gave ambiguous results. One way or another, we failed to obtain both compound 4 and, in general, a product having physicochemical or spectral characteristics reported in [9]. It was found that the direction of the reaction is strongly dependent on its conditions. For example, after the mixture of reagents in pyridine was first allowed to stand at room temperature and then refluxed, we obtained, in a low yield (8\%), a beige substance melting above $300{ }^{\circ} \mathrm{C}$ and insoluble in boiling EtOH.

Detailed analysis of the spectral data showed that the product is not pyrimidine 4 , and allowed it to be assigned the structure 4,6-diamino-2-(phenylimino)-
2H-thiopyran-3,5-dicarbonitrile 6 (Scheme 2; Table 1, entry 3 ). At the same time, the reaction of malononitrile dimer 1 with PhNCS, when carried out in boiling pyridine from the very beginning, gives a yellow orange product (decomp. point $>300^{\circ} \mathrm{C}$ after purification, instead of the green crystals with $\mathrm{mp} 225^{\circ} \mathrm{C}$, reported in [9]), which, according to the IR and NMR data, is impure 4,6-diamino2-thioxo-1-phenyl-1,2-dihydropyridine-3,5-dicarbonitrile 2 (Table 1, entry 4).

The reaction of dimer $\mathbf{1}$ with allyl isothiocyanate in boiling pyridine formed an orange product (yield 37$47 \%$, based on the expected $1: 1$ adduct). The IR spectra of the product showed absorption bands corresponding to stretching vibrations of the $\mathrm{N}-\mathrm{H}$ group (3323 and $\left.3207 \mathrm{~cm}^{-1}\right)$ and conjugated cyano group $\left(2197 \mathrm{~cm}^{-1}\right)$. However, the synthesized compound could not be characterized by ${ }^{1} \mathrm{H}$ and ${ }^{13} \mathrm{C}$ NMR spectroscopy because of its low solubility in organic solvents, including DMSO.

Table 1. Conditions, yields and products of the reaction of malononitrile dimer $\mathbf{1}$ with isothiocyanates

\begin{tabular}{|c|c|c|c|}
\hline Entries & Reagents & Conditions & $\begin{array}{l}\text { Reaction product } \\
\text { (yield, } \%)\end{array}$ \\
\hline 1 & $\mathbf{1}, \mathrm{PhNCS}$ & $\mathrm{DMF} \mathrm{Et}_{3} \mathrm{~N}$ (cat.), reflux $2 \mathrm{~h} \mathrm{[5]}$ & $2(74 \%)$ \\
\hline 2 & 1, $\mathrm{PhNCS}$ & $\mathrm{EtOH}, \mathrm{Et}_{3} \mathrm{~N}$ ( $1-1.5$ equiv), $25^{\circ} \mathrm{C}$ & $2(84-92 \%)$ \\
\hline 3 & 1, $\mathrm{PhNCS}$ & Pyridine, $24 \mathrm{~h} 25^{\circ} \mathrm{C} \rightarrow$ reflux, $2 \mathrm{~h}$ & $6(8 \%)$ \\
\hline 4 & 1, $\mathrm{PhNCS}$ & Pyridine, reflux, 2 h [9] & $2(48 \%)$ \\
\hline 5 & $\mathbf{1}, \mathrm{H}_{2} \mathrm{C}=\mathrm{CHCH}_{2} \mathrm{NCS}$ & $\mathrm{EtOH}, \mathrm{Et}_{3} \mathrm{~N}$ (cat.), $25^{\circ} \mathrm{C}$ & No reaction \\
\hline 6 & $\mathbf{1}, \mathrm{H}_{2} \mathrm{C}=\mathrm{CHCH}_{2} \mathrm{NCS}$ & $\mathrm{EtOH}, \mathrm{Et}_{3} \mathrm{~N}$ ( $1-1.5$ equiv), $25^{\circ} \mathrm{C}$ & $5(58-73 \%)$ \\
\hline 7 & $\mathbf{1}, \mathrm{H}_{2} \mathrm{C}=\mathrm{CHCH}_{2} \mathrm{NCS}$ & $\mathrm{DMSO}, \mathrm{KOH}$ ( 1 equiv), $25^{\circ} \mathrm{C}$ & $5(71 \%)$ \\
\hline 8 & $\mathbf{8}, \mathrm{H}_{2} \mathrm{C}=\mathrm{CHCH}_{2} \mathrm{NCS}$ & $\mathrm{EtOH}, 25^{\circ} \mathrm{C}$ & $5(27 \%)$ \\
\hline 9 & 8, PhNCS & $\mathrm{EtOH}, 25^{\circ} \mathrm{C}$ & $6(82 \%)$ \\
\hline
\end{tabular}


Scheme 2.

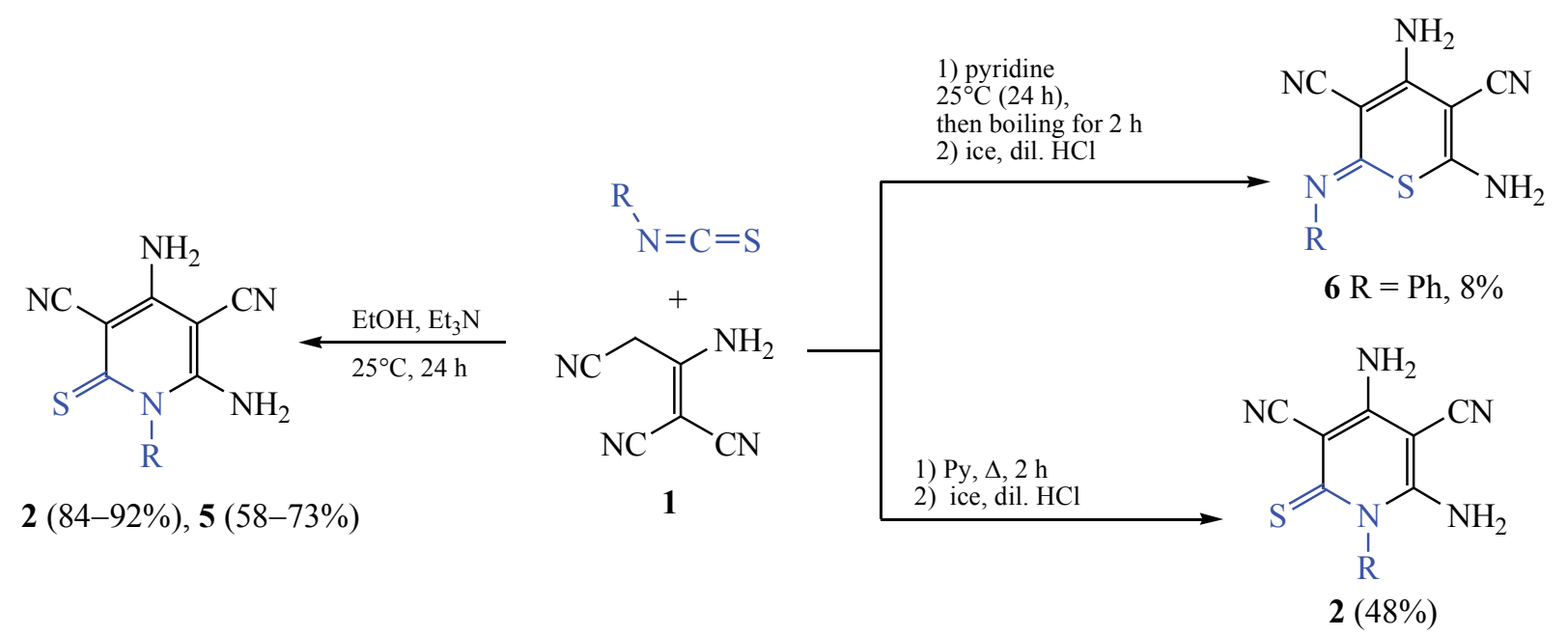

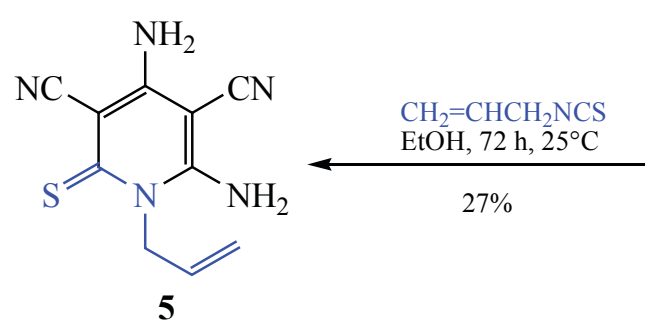

$\mathrm{R}=\mathrm{Ph}(\mathbf{2}, \mathbf{6})$, allyl (5).

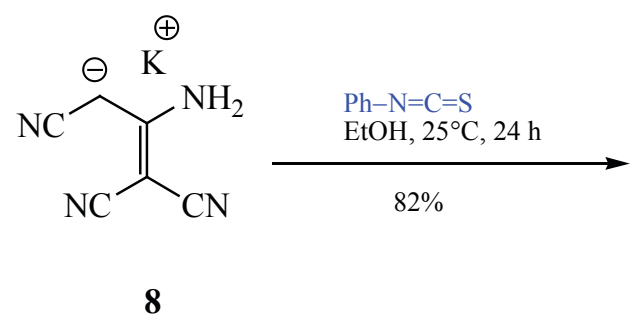<smiles>N#CC1=C(N)/C(=N\c2ccccc2)C(C#N)=C1N</smiles>

Malononitrile dimer potassium salt $\mathbf{8}$ reacts with isothiocyanates differently from malononitrile dimer 1. For example, the reaction of salt $\mathbf{8}$ with allyl isothiocyanate give the same 1-allyl-4,6-diamino-2thioxo-1,2-dihydropyridine-3,5-dicarbonitrile 5 but in an appreciably lower yield (27\%) (Scheme 2; Table 1, entry 8 ). At the same time, the reaction of salt 8 with $\mathrm{PhN}=\mathrm{C}=\mathrm{S}$ under analogous conditions leads to thiopyran 6 in a yield of $82 \%$ (Table 1, entry 9 ). It should be noted that we failed to recyclize thiopyran $\mathbf{6}$ into 2-thioxopyridine $\mathbf{2}$ even upon prolonged boiling in alcoholic $\mathrm{KOH}$.

Thiopyran 6 has never been described in the literature, but the formation of structurally similar $2 \mathrm{H}$-thiopyrans was previously observed in the reactions of cyclohexylidenemalononitrile with PhNCS [22], ammonolysis of thiopyran salts [23], condensation of malononitrile with enamines $\beta$-ketothioanilides [24], and reactions of malononitrile or its dimer with carbon disulfide in the presence of alkalis [25] (Scheme 3).

The structures of 2-thioxopyridines $\mathbf{2}$ and $\mathbf{5}$ and 2-iminothiopyran 6 were studied in detail by IR and NMR spectroscopy $\left({ }^{1} \mathrm{H},{ }^{13} \mathrm{C}\right.$ DEPTQ, ${ }^{1} \mathrm{H}-{ }^{13} \mathrm{C}$ HSQC,${ }^{1} \mathrm{H}-{ }^{13} \mathrm{C}$
HMBC). The spectra are presented in Supplementary Information.

The ${ }^{1} \mathrm{H}$ NMR spectra of compounds $\mathbf{2 , 5}$, and $\mathbf{6}$ show signals of the substituent $\mathrm{R}$ and broadened signals of two amino groups. The ${ }^{13} \mathrm{C}$ (DEPTQ) NMR spectra of all the compounds show signals of two $\mathrm{C} \equiv \mathrm{N}$ carbons and 5 characteristic signals of the heteroring carbons. Evidence for the structures is provided by the results of heteronuclear correlation experiments. Thus, the ${ }^{1} \mathrm{H}-{ }^{13} \mathrm{C}$ HMBC spectra of compounds $\mathbf{2}, \mathbf{5}$, and $\mathbf{6}$ contain cross peaks between the protons of one of the amino groups and two signals of the heteroring carbons in the high-field region $\left(\mathrm{C}^{3}\right.$ and $\left.\mathrm{C}^{5}\right)$, which unambiguously confirms the presence of the $\mathrm{N} \equiv \mathrm{C}-\mathrm{C}^{3}=\mathrm{C}^{4}\left(\mathrm{NH}_{2}\right)-\mathrm{C}^{5}-\mathrm{C} \equiv \mathrm{N}$ fragment (see Supplementary Information). At the same time, the spectra of isomeric compounds $\mathbf{2}$ and $\mathbf{6}$ differ from each other in the low-field region: in the spectrum of compound 2, the pyridine $C^{4}$ and $C^{6}$ signals are observed at 155.6 and $155.9 \mathrm{ppm}$ and the signal assignable to the thiocarbonyl $\mathrm{C}^{2}=\mathrm{S}$ carbon, at $181.0 \mathrm{ppm}$, whereas the respective signals in the spectrum of thiopyran 6 are present at $156.7\left(\mathrm{C}^{6}\right)$, $159.3\left(\mathrm{C}^{4}\right)$, and $160.4\left(\mathrm{C}^{2}\right) \mathrm{ppm}$. 


\section{Scheme 3.}

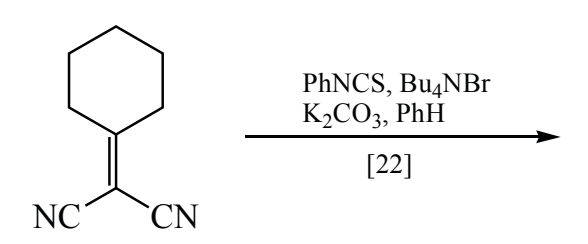<smiles>N#Cc1c(N)s/c(=N/c2ccccc2)c2c1CCCC2</smiles><smiles>N#Cc1c2c(c(=S)n(-c3ccccc3)c1N)CCCC2</smiles><smiles>N#Cc1c2c(c(=O)n(-c3ccccc3)c1N)CCCC2</smiles><smiles></smiles><smiles>N#Cc1c(N)s/c(=N/c2ccccc2)c2c1CCCC2</smiles><smiles>S=C(Nc1ccccc1)C1=C(N2CCOCC2)CCCC1</smiles><smiles>N#CC/C(N)=C(/C#N)C(=O)O</smiles>

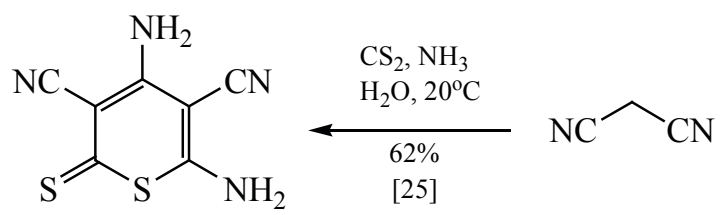

The IR spectra of compounds $\mathbf{2}, \mathbf{5}$, and $\mathbf{6}$ contain stretching vibration bands of the $\mathrm{N}-\mathrm{H}$ bonds and conjugated $\mathrm{C} \equiv \mathrm{N}$ groups $\left(2204-2212 \mathrm{~cm}^{-1}\right)$. At the same time, the spectra of thiones $\mathbf{2}$ and $\mathbf{5}$ show vibration bands of the $\mathrm{C}=\mathrm{S}$ bond (strong bands at $1344-1348 \mathrm{~cm}^{-1}$ and medium intensity bands at $1180-1190 \mathrm{~cm}^{-1}$ ).

Quantum-chemical study. Further evidence for the structure of compounds $\mathbf{2 , 5}$, and $\mathbf{6}$ was obtained by the quantum-chemical calculations of spectral modes. For example, the molecular geometry (Fig. 1) and IR spectra, calculated using the ORCA 4.2 software package $[26,27]$, at the B3LYP-D3BJ level of theory [28-31] with the $6-311+G(2 d, p)$ split-valence basis set, showed a good fit to the experimental spectra (Tables 2 and 3 ). The calculated and experimental frequencies were compared using scale factors [0.9679 for high-frequency $\left(>1000 \mathrm{~cm}^{-1}\right)$ and 1.0100 for low-frequency modes $\left(<1000 \mathrm{~cm}^{-1}\right)$ ] [32]. The input files were generated using the Gabedit 2.5 program [33]. The ChemCraft 1.8 program was used to visualize the molecular geometries and calculated IR spectra.

Quantum-chemical calculations were also applied to interpret the experimental results, in particular, the different regioselectivities of the heterocyclizations of phenyl isothiocyanate with malononitrile dimer. The mechanisms of intramolecular cyclization were calculated

Table 2. Comparison of the principal absorption bands in the experimental and calculated IR spectra of 4,6-diamino-2-thioxo1-phenyl-1,2-dihydropyridine-3,5-dicarbonitrile 2

\begin{tabular}{c|c|c|c}
\hline & & \multicolumn{2}{|c}{ Calculated absorption bands, $v, \mathrm{~cm}^{-1}$} \\
\cline { 3 - 4 } Assignment & Experimental absorption bands, $v, \mathrm{~cm}^{-1}$ & corrected & uncorrected \\
\cline { 3 - 4 }$v_{\text {as }}(\mathrm{N}-\mathrm{H})$ & $3336.4,3301.7$ & $3705.4,3693.3$ & $3586.5,3574.7$ \\
$v_{\mathrm{s}}(\mathrm{N}-\mathrm{H})$ & 3211.1 & $3583.0,3569.6$ & $3468.0,3455.0$ \\
$v(\mathrm{C} \equiv \mathrm{N})$ & 2206.3 & $2297.7,2283.3$ & $2223.9,2210.0$ \\
$\delta\left(\mathrm{NH}_{2}\right)$ & 1635.4 & $1659.1,1646.0$ & $1605.9,1593.2$ \\
Skeletal $v(\mathrm{C}=\mathrm{C})$ & $1564.1,1523.6,1485.0$ & $1585.1,1532.5,1527.1$ & $1534.2,1483.3,1478.1$ \\
$v(\mathrm{C}-\mathrm{N})$ & 1454.1 & 1483.6 & 1436.0 \\
$v(\mathrm{C}=\mathrm{S})$ & 1348.1 & 1366.7 & 1322.8 \\
Skeletal & $1222.7,1180.3$ & $1234.3,1178.2$ & $1194.7,1140.4$ \\
$v(\mathrm{C}=\mathrm{S})$ & 1029.9 & 1052.2 & 1018.5 \\
\hline
\end{tabular}



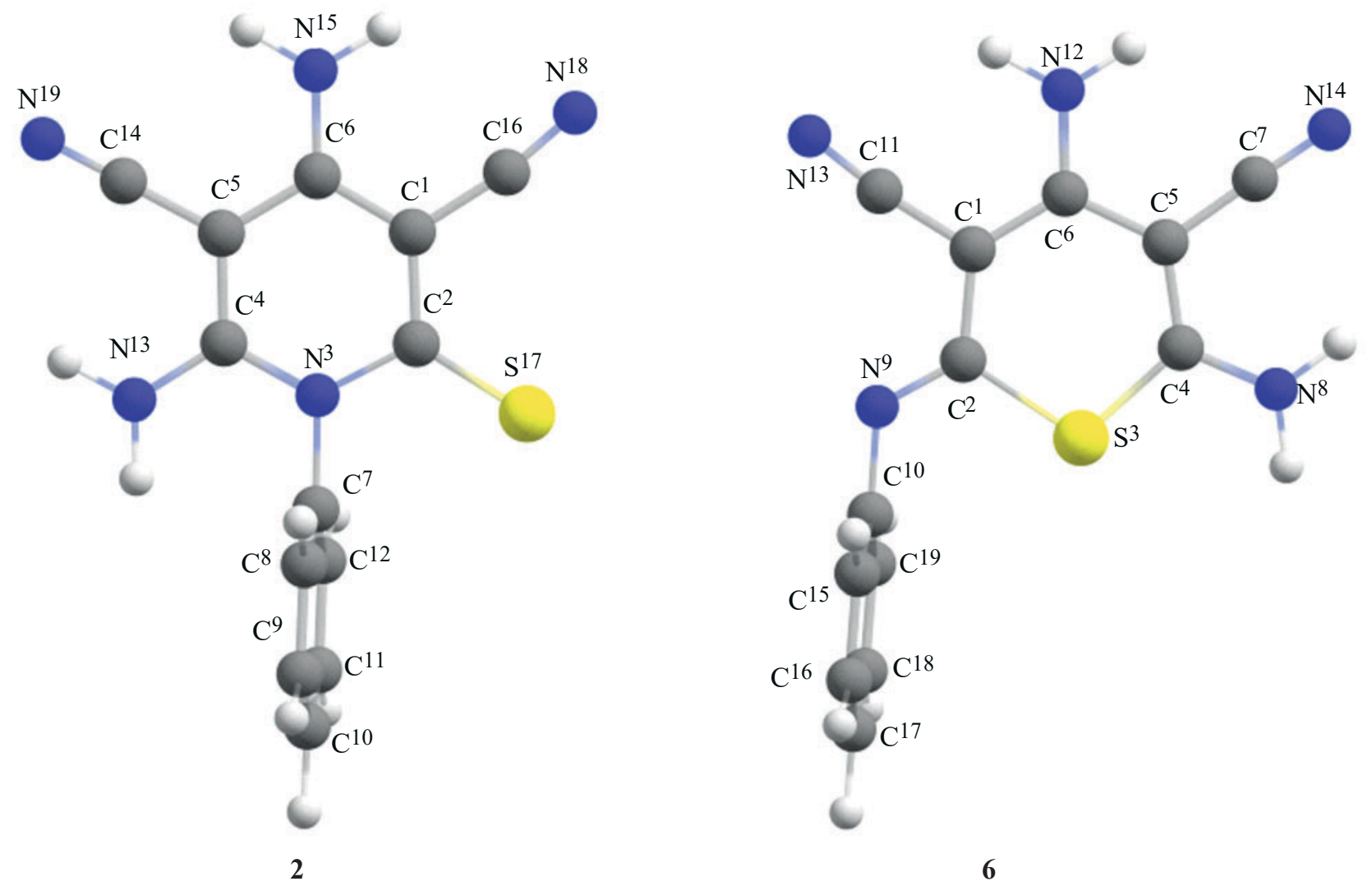

Fig. 1. Optimized structures of the cyclization products [calculation at the B3LYP-D3BJ/6-311+G(2d,p) level].

using the ORCA 4.2 software package [26, 27]. The search for transition states and reaction paths, as well as calculation of the vibration modes and Gibbs free energies were performed using the DFT method with the Grimme B97-3c scheme [34, 35], which combines the B97 GGA functional and the def2-mTZVP basis set with the D3BJ dispersion correction [36]. The obtained transition state geometry was confirmed by the presence of an imaginary vibration frequency corresponding to the reaction coordinate. All calculations were performed with the inclusion of nonspecific solvation in the framework of the CPCM model [37].

To find out what of the two variants of the cyclization reaction (leading to 2 -thioxopyridine 2 or to

Table 3. Comparison of the principal absorption bands in the experimental and calculated IR spectra of 4,6-diamino-2(phenylimino)-2H-thiopyran-3,5-dicarbonitrile 6

\begin{tabular}{c|c|c|c}
\hline \multirow{2}{*}{ Assignment } & Experimental absorption bands, & \multicolumn{2}{|c}{ Calculated absorption bands, $v, \mathrm{~cm}^{-1}$} \\
\cline { 2 - 4 } & $v, \mathrm{~cm}^{-1}$ & corrected & uncorrected \\
\hline$v_{\text {as }}(\mathrm{N}-\mathrm{H})$ & $3351.8,3326.8$ & $3700.4,3694.6$ & $3581.6,3576.0$ \\
$v_{\mathrm{s}}(\mathrm{N}-\mathrm{H})$ & 3234.2 & $3572.3,3570.8$ & $3457.7,3456.1$ \\
$v(\mathrm{C} \equiv \mathrm{N})$ & 2212.1 & $2291.9,2281.6$ & $2218.4,2208.4$ \\
$v(\mathrm{C}=\mathrm{N})$ & 1643.1 & 1681.4 & 1627.4 \\
$\delta\left(\mathrm{NH}_{2}\right)$ & 1604.6 & $1662.0,1652.9$ & $1608.6,1599.9$ \\
$v(\mathrm{C}=\mathrm{C})$ & 1564.7, & 1629.3, & 1577.0, \\
Skeletal & $1521.6,1488.9$ & $1580.7,1513.0$ & $1529.9,1464.5$ \\
$v(\mathrm{C}-\mathrm{N})$ & 1456.1 & 1448.4 & 1401.9 \\
Skeletal & $1282.5,1153.3$ & $1327.1,1234.4$ & $1284.5,1194.8$ \\
\hline
\end{tabular}


Scheme 4.

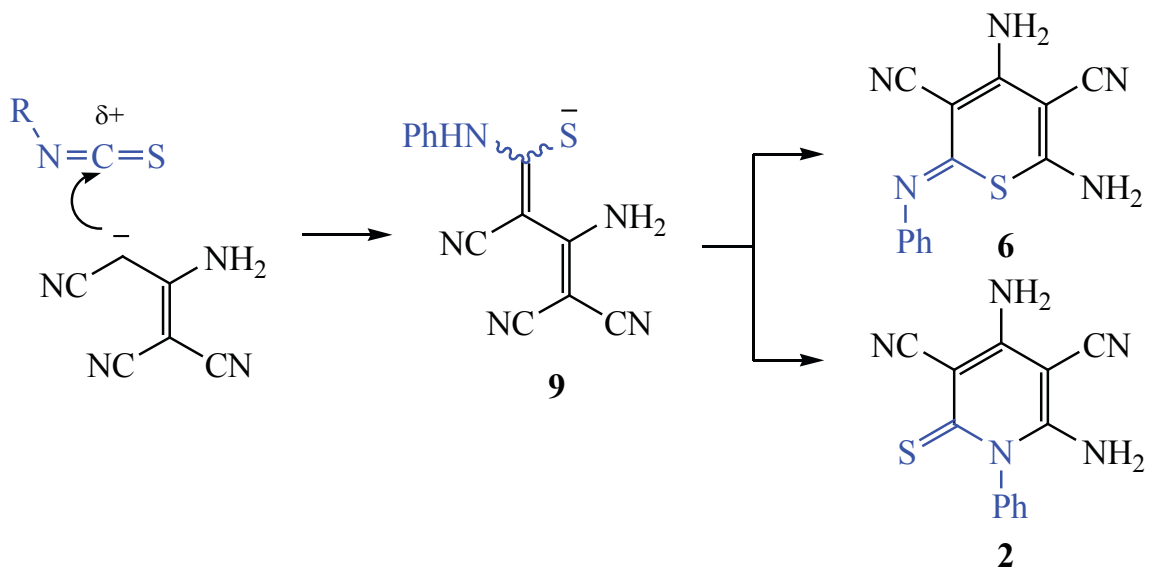

2-iminothiopyran 6), we compared the calculated reaction paths. The obvious intermediate, both for pyridine $\mathbf{2}$ and for thiopyran 6) is anion 9 formed by the nucleophilic attack of the anion of malononitrile dimer on the central carbon atom of isothiocyanate (Scheme 4).

Since the reaction was carried out with an excess of a base (triethylamine) in ethanol or pyridine (as a solvent), as the initial structure we considered anion $\mathbf{9}$ associated with two base molecules, one of which was protonated and thus formed an ion pair with anion 9 and the second was hydrogen-bonded to the $\mathrm{H}^{22}$ proton (Fig. 2a). To determine the optimal geometry of the initial state, a search was for the most stable conformation of anion 9 was first performed.

The cyclization leading to 2-thioxopyridine 2 occurs as a result of the nucleophilic attack of $\mathrm{N}^{13}$ on $\mathrm{C}^{6}$, accompanied by $\mathrm{H}^{45}$ transfer from the base molecule to $\mathrm{N}^{8}$ and deprotonation of $\mathrm{N}^{13}$ by the second base (triethylamine or pyridine) molecule (Figs. 2b and 2d). The reaction leading to thiopyran 6 involves the nucleophilic attack of $\mathrm{S}^{12}$ on $\mathrm{C}^{6}$, accompanied by proton transfer from the base molecule to $\mathrm{N}^{8}$ (Figs. 2c and 2e). The subsequent deprotonation of $\mathrm{N}^{13}$ by the second base molecule has, according to the calculations, very low activation energy, and, therefore, it is not a rate-limiting stage.

The molecular structures of starting anion $\mathbf{9}$, transition states, and cyclization products are presented in Fig. 2 (reaction in pyridine). The calculations showed that the cyclization leading to thiopyran 6 is a kinetically controlled reaction. The activation energy is $70.2 \mathrm{~kJ} / \mathrm{mol}$. At the same time, the heat effect of this reaction is low $(-9.1 \mathrm{~kJ} / \mathrm{mol})$. The activation energy of the cyclization, leading to 2-thioxopyridine 2 , is $91.5 \mathrm{~kJ} / \mathrm{mol}$, but its heat effect is higher $(-36.6 \mathrm{~kJ} / \mathrm{mol})$. Thus, under the thermodynamic control, 2-thioxopyridine 2 should be the main reaction product.

The simulation of analogous process in the ethanol medium (the resulting molecular structures are presented in Fig. 3) showed that the activation energy of the cyclization reaction in the presence of triethylamine as a base increases to $138.2 \mathrm{~kJ} / \mathrm{mol}$, and the heat effect of this reaction also increases $(-48.2 \mathrm{~kJ} / \mathrm{mol})$. Presumably, the reason why this process has a higher activation energy compared to the same reaction in pyridine is the mutual repulsion of the two bulky triethylamine molecules, which are getting closer together during reaction, and the resulting distortion of the molecular structure of the reacting substrate. Thus, the benzene ring on the $\mathrm{N}^{13}$ atom takes a position almost perpendicular to the forming pyridine ring. The cyclization involving the sulfur atom, while having a slightly lower activation energy $(65.2 \mathrm{~kJ} / \mathrm{mol})$, has a negative heat effect $(4.5 \mathrm{~kJ} / \mathrm{mol})$, and, therefore, it is unlikely to occur. The energy profiles of the cyclization reactions in study are shown in Fig. 4.

Thus, having considered the simulated cyclization mechanisms allow us to conclude that 2-iminothiopyrans are formed under kinetic control, whereas 2-thioxopyridines are formed under thermodynamic control. The observed formation of 2-iminothiopyran in pyridine $\left(25^{\circ} \mathrm{C}\right.$ to refluxing) can be explained by the fact that initially, still at $25^{\circ} \mathrm{C}$ (before heating is applied), the reaction occurs under kinetically controlled conditions to form 2-iminothiopyran $\mathbf{6}$ which further is unable to undergo recyclization into 2-thioxopyridine $\mathbf{2}$ (the difficulty of the latter process was confirmed experimentally). The 
(a)

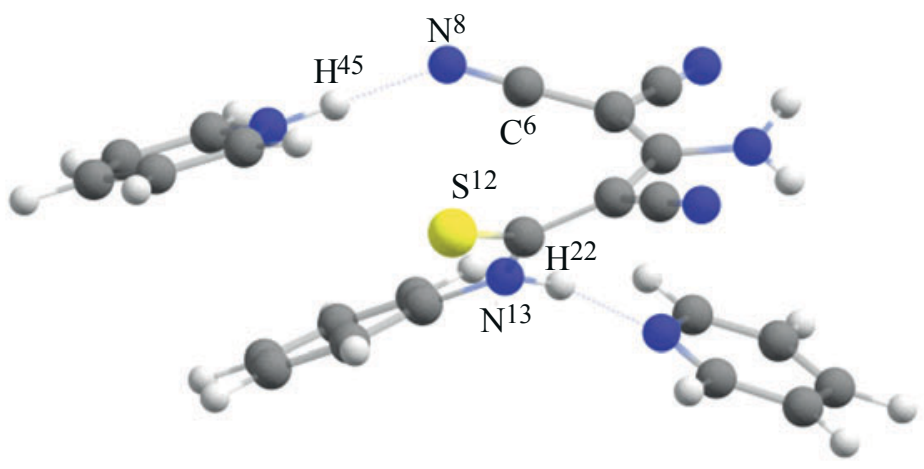

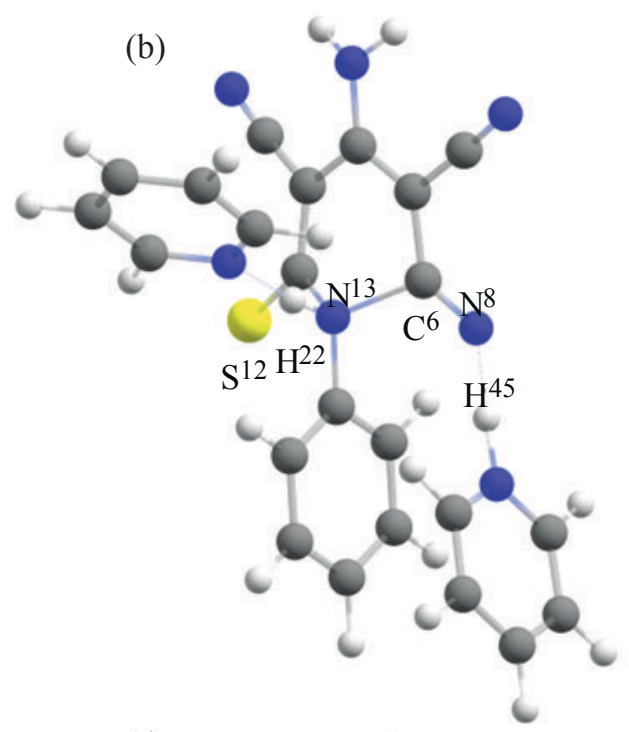

(d)

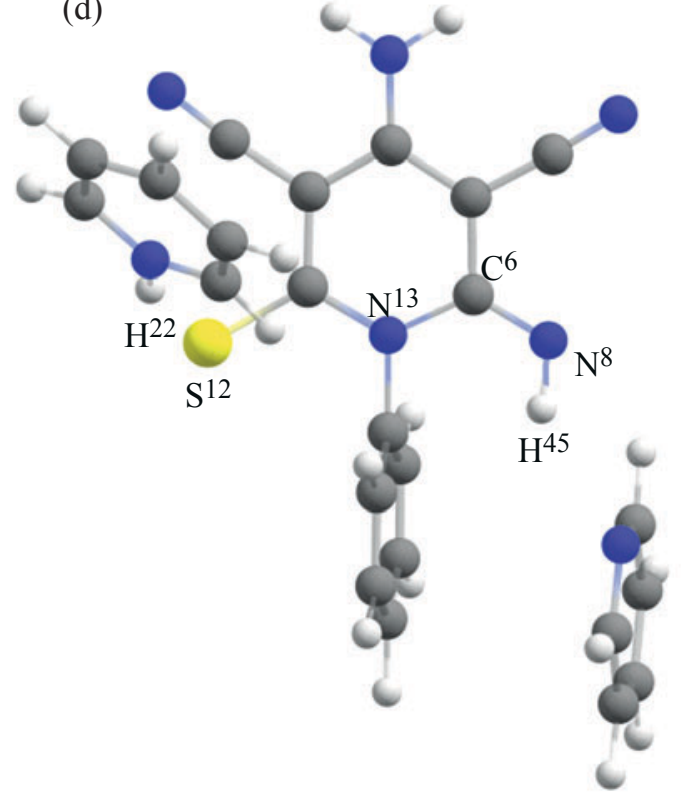

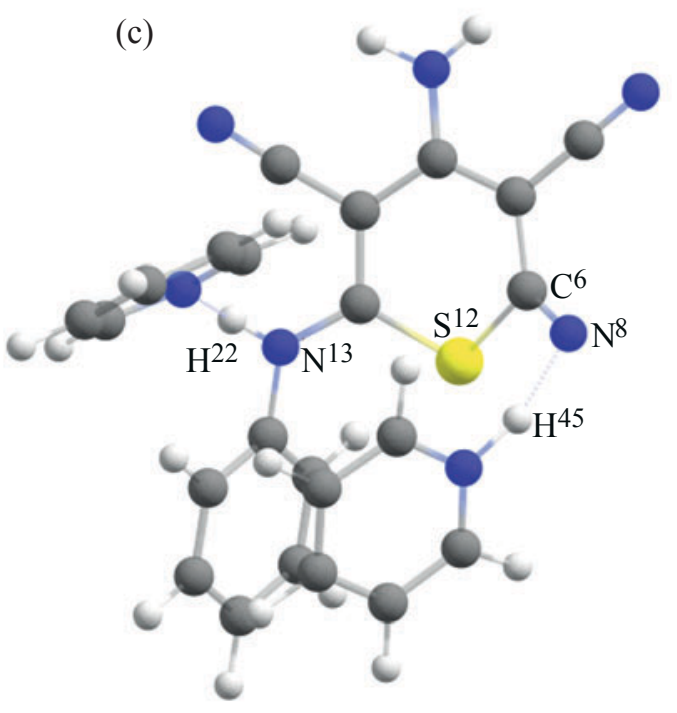

(e)

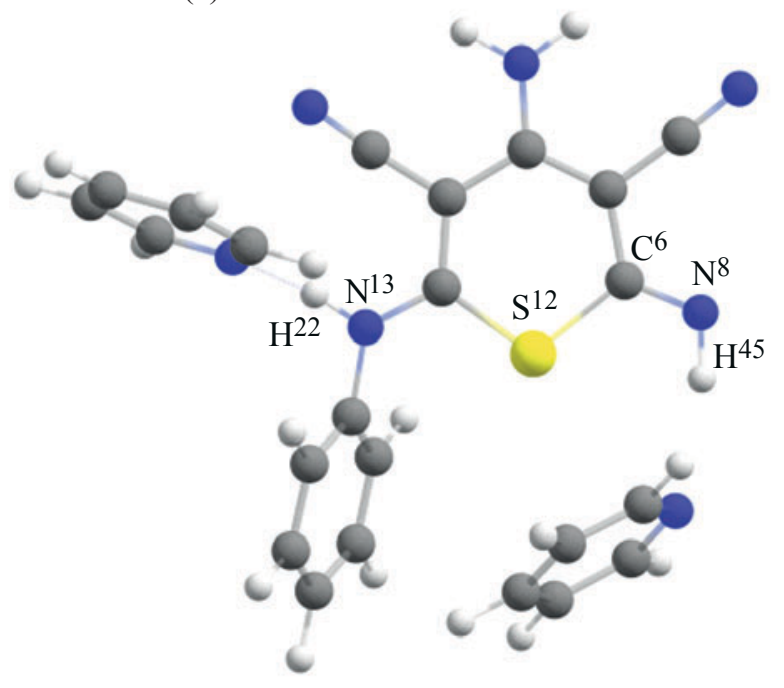

Fig. 2. Molecular structures of (a) starting anion 9 associated with two pyridine molecules, (b, c) transition states of the cyclization reactions and products of the cyclization by the (d) nitrogen atom $\mathrm{N}^{13}$ and (e) sulfur atom $\mathrm{S}^{12}$ (geometry optimization at the B97-3c level). 


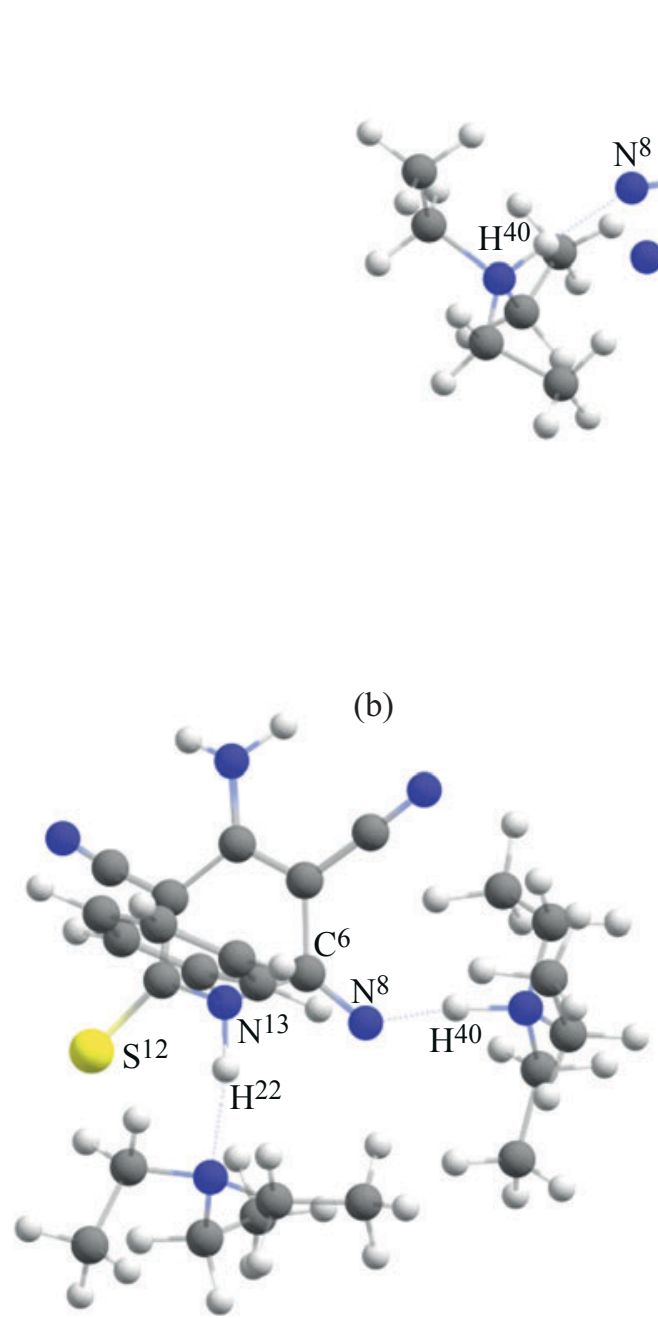

(d)

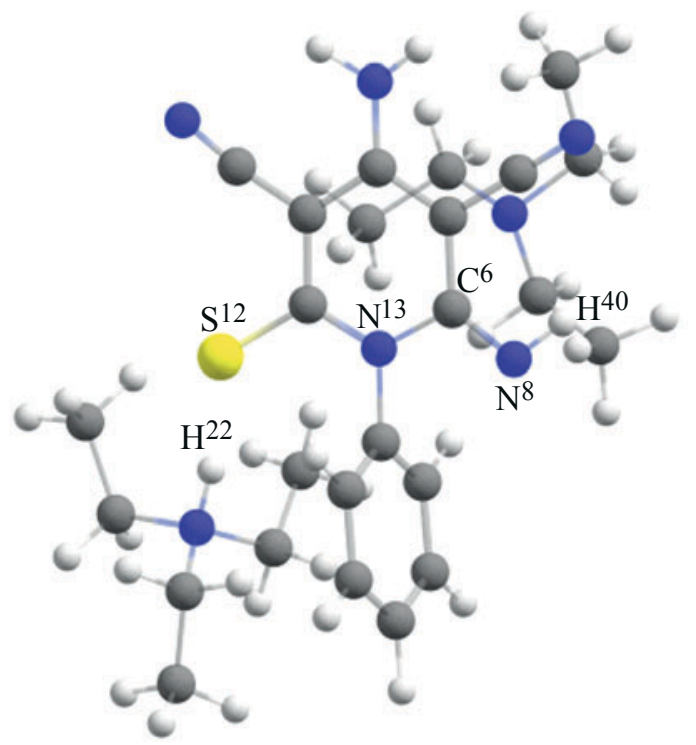

(a)

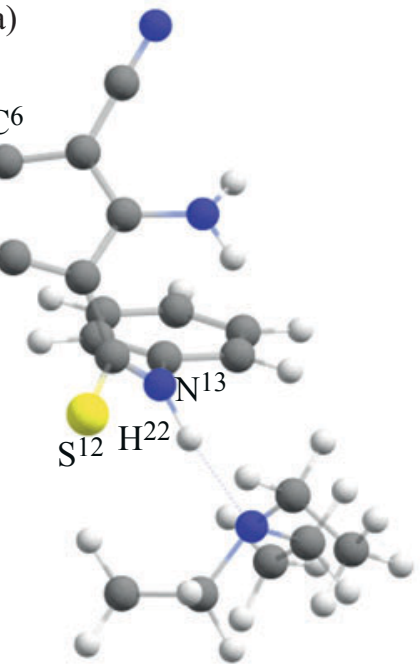

(c)

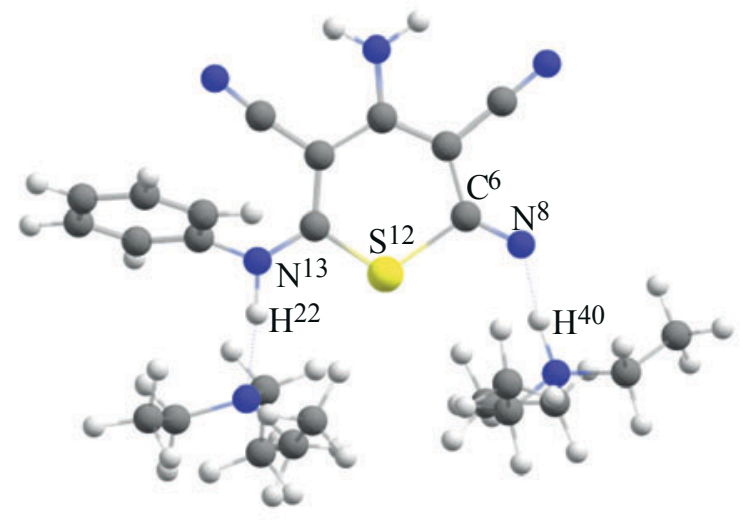

(e)

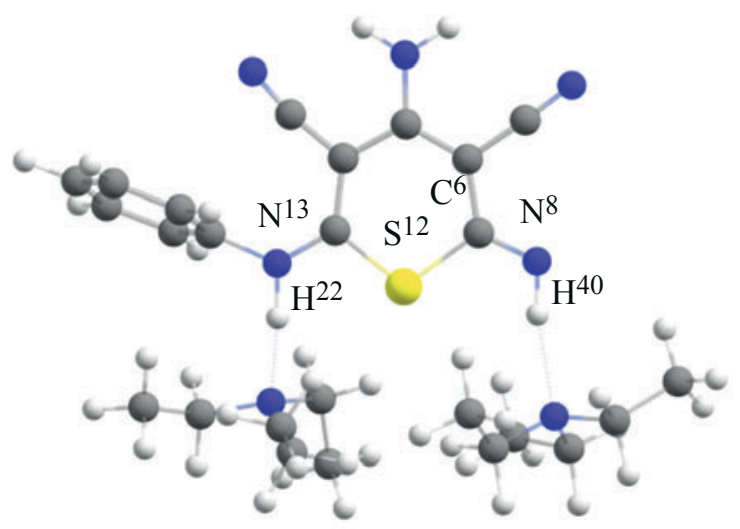

Fig. 3. Molecular structures of (a) starting anion 9 associated with two triethylamine molecules, (b, c) transition states of the cyclization reactions and products of the cyclization by the (d) nitrogen atom $\mathrm{N}^{13}$ and (e) sulfur atom $\mathrm{S}^{12}$ (geometry optimization at the B97-3c level). 
different regioselectivities of the reactions of $\mathrm{PhNCS}$ with malononitrile dimer $\left(\mathrm{Et}_{3} \mathrm{~N}, \mathrm{EtOH}, 25^{\circ} \mathrm{C}\right)$ and with its potassium salt $\left(\mathrm{EtOH}, 25^{\circ} \mathrm{C}\right)$ can be explained by a specific role of the base catalyst. Successful formation of 2-thioxopyridine 2 requires involvement of two base molecules: to form an unstable multi-charged transition state 10 (Scheme 5) requires simultaneous deprotonation of the endocyclic nitrogen atom with a free base and protonation of the negatively charged exocyclic nitrogen atom with the pyridinium (triethylammonium) cation.

However, in the case of malononitrile dimer salt $\mathbf{8}$, such base and its protonated form are absent from the reaction medium. Water and ethanol, that are present in the reaction medium, are weaker proton donor/acceptors than pyridine or triethylamine and their conjugate acids; therefore, in this case, the reaction proceeds exclusively by the way of formation of kinetic product 6 .

In our opinion, the different results obtained with allyl isothiocyanate can be associated with more facile recyclization of the 2-iminothiopyran product. However, this issue calls for a more detailed study, which will be the subject of our further research.

In silico assessment of biological activity. 6-Amino2-thioxopyridine-3,5-dicarbonitriles and their derivatives exhibit broad-spectrum biological activity (see reviews [38-42] and recent works [43-48]), which makes them promising objects for study. The biological activity of 2-aminothiopyran-3,5-dicarbonitriles was also reported [49-51]. We performed a predictive analysis and in silico calculations of the potential targets, ADMET parameters, and compliance with the bioavailability parameters for compounds 2, 5, and 6. Analysis of the structures of compounds $\mathbf{2 , 5}$, and $\mathbf{6}$ for the compliance with Lipinski's rule of five [molecular weight $(\mathrm{MW}) \leq 500, c \log P \leq$ 5.0, TPSA $\leq 140 \AA^{2}$, H-bond acceptors $\leq 10$, H-bond donors $\leq 5]$ [52-54] was performed using the OSIRIS Property Explorer software package [55]. The following parameters were calculated: $c \log P$ [logarithm of the

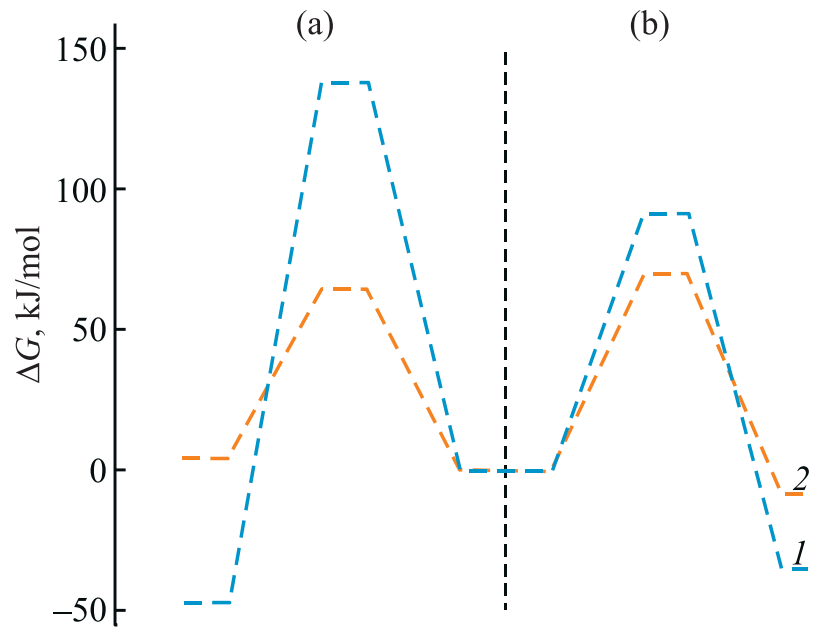

Fig. 4. Energy profiles of the cyclization reactions by the (1) nitrogen atom $\mathrm{N}^{13}$ and (2) sulfur atom $\mathrm{S}^{12}$ in (a) ethanol with triethylamine and (b) pyridine.

$n$-octanol/water partition coefficient $\left.\log \left(c_{\text {octanol }} / c_{\text {water }}\right)\right]$, solubility $(\log S)$, topological polar surface area (TPSA), toxicity parameters: risks of side effects (mutagenic, oncogenic, and reproductive effects), parameter of similarity to known drugs (drug likeness), as well as general pharmacological assessment of a compound (drug score). The calculated data are presented in Table 4.

As we can see from the data in Table 4, the $c \log P$ values for compounds $\mathbf{2}, \mathbf{5}$, and $\mathbf{6}$ vary from -0.95 to -0.13 , which suggests good absorption and permeation [52-54]. At the same time, the $\log S$ value of lower than -4.0 for compound 2 points to a lower solubility $\left(<1 \times 10^{-4} \mathrm{M}\right)$. The TPSA parameters for all the compounds have borderline values, even though they all formally fit the oral bioavailability criteria. No toxicity risks predicted for compounds $\mathbf{2}, \mathbf{5}$, and $\mathbf{6}$. The drug likeness indices are low, but the drug scores, due to the formal compliance with the bioavailability criteria and predicted low toxicity, are fairly high $(0.37-0.48)$.

\section{Scheme 5.}

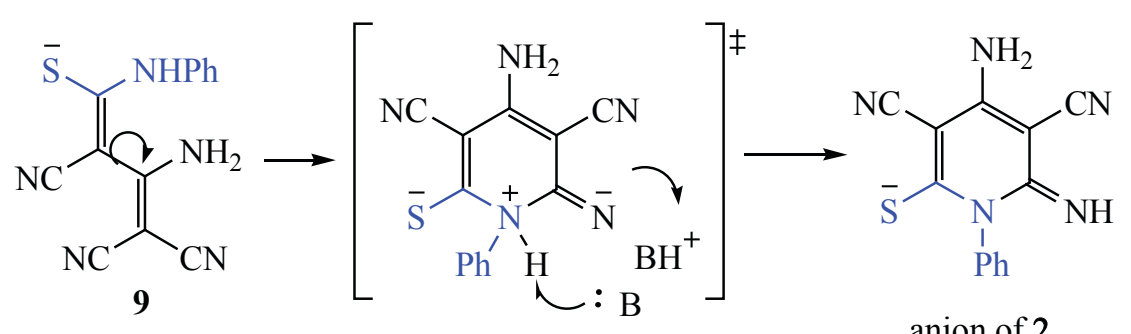


Table 4. Toxicity risks and physicochemical parameters of compounds 2, 5, and 6, predicted by OSIRIS Property Explorer

\begin{tabular}{c|c|c|c|c|c|c|c|c|c|c}
\hline \multirow{2}{*}{ Comp. no. } & \multicolumn{4}{|c|}{ Toxicity risks $^{\mathrm{a}}$} & \multicolumn{9}{c}{ Physicochemical parameters } \\
\cline { 2 - 12 } & A & B & C & D & $c \log P$ & $\log S$ & MW & TPSA & drug likeness & drug score \\
\hline $\mathbf{2}$ & - & - & - & - & -0.13 & -5.14 & 267 & 134.9 & -2.83 & 0.37 \\
$\mathbf{5}$ & - & - & - & - & -0.95 & -3.81 & 231 & 134.9 & -4.92 & 0.44 \\
$\mathbf{6}$ & - & - & - & - & -0.23 & -2.79 & 267 & 137.2 & -3.35 & 0.48 \\
\hline
\end{tabular}

${ }^{a}(-)$ Predicted lack of toxicity: (A) mutagenicity, (B) carcinogenicity, (C) irritating effect, and (D) reproductive effects.

Table 5. Calculated ADMET parameters for compounds 2, 5, and $\mathbf{6}$

\begin{tabular}{|c|c|c|c|c|c|c|c|c|c|c|c|}
\hline \multirow[b]{2}{*}{$\begin{array}{l}\text { Comp. } \\
\text { no. }\end{array}$} & \multirow[b]{2}{*}{$\begin{array}{l}\text { Penetration } \\
\text { through } \mathrm{BBB}^{\mathrm{a}}\end{array}$} & \multirow[b]{2}{*}{$\begin{array}{l}\text { Gastrointestinal } \\
\text { absorption }^{\mathrm{a}}\end{array}$} & \multicolumn{5}{|c|}{$\begin{array}{l}\text { Inhibition of cytochromes } \\
\qquad \mathrm{P} 450^{\mathrm{a}}\end{array}$} & \multicolumn{4}{|c|}{$\begin{array}{l}\text { Acute toxicity (rats), LD50, } \log _{10} \\
\qquad(\mathrm{mmol} / \mathrm{kg})\end{array}$} \\
\hline & & & $\frac{2}{2}$ & 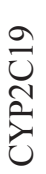 & 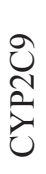 & 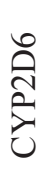 & 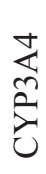 & $\mathrm{IP}^{\mathrm{b}}$ & $\mathrm{IV}^{\mathrm{b}}$ & Oral $^{b}$ & $\mathrm{SC}^{\mathrm{b}}$ \\
\hline 2 & - & + & + & - & + & - & + & $\begin{array}{c}-0.054 \\
235.4\end{array}$ & $\begin{array}{c}-0.403 \\
105.4\end{array}$ & $\begin{array}{l}0.316 \\
551.9\end{array}$ & $\begin{array}{l}0.006 \\
270.0\end{array}$ \\
\hline 5 & - & + & + & - & - & - & - & $\begin{array}{l}0.208 \\
373.0\end{array}$ & $\begin{array}{c}-0.178 \\
153.4\end{array}$ & $\begin{array}{l}0.601 \\
922.5\end{array}$ & $\begin{array}{l}0.083 \\
279.7\end{array}$ \\
\hline 5 & - & + & + & - & - & - & - & $\begin{array}{l}0.170 \\
395.5\end{array}$ & $\begin{array}{c}-0.250 \\
150.2\end{array}$ & $\begin{array}{l}0.375 \\
634.5\end{array}$ & $\begin{array}{l}0.413 \\
691.7\end{array}$ \\
\hline
\end{tabular}

${ }^{a}(+)$ or $(-)$ Presence or the lack.

b Administration route: (IP) intraperitoneal, (IV) intravenous, (Oral) peroral, and (SC) subcutaneous.

To predict biological activity, we also used the open source software PASS Online [56, 57] and AntiBac-Pred [58]. The resulting data predict an inhibitory effect on kinases for compound $\mathbf{2}$ with a probability of 0.765 , an anti-ischemic effect for compound $\mathbf{5}$ with a probability of 0.800 , as well as activity against the $\beta$-amyloid precursor protein for thiopyran 6 with a probability of 0.800 . The highest antibacterial effect with respect to Campylobacter jejuni bacteria is predicted for compound $\mathbf{6}$ (confidence 0.3158 ; confidence $>0$, if the probability of activity is greater than the probability of inactivity $P_{\mathrm{a}}>P_{\mathrm{i}}$ ).

The SwissADME [59, 60] and GUSAR [61, 62] software packages were used to predict the ADMET parameters (absorption, distribution, metabolism, excretion, toxicity). According to the US EPA criteria, in terms of acute oral toxicity, compounds $\mathbf{2}, \mathbf{5}$, and $\mathbf{6}$ can be assigned to class III (for low toxicity compounds, $500 \mathrm{mg} / \mathrm{kg}<\mathrm{LD}_{50}<5000 \mathrm{mg} / \mathrm{kg}$ ). Gastroenteric absorption, lack of ability to penetrate the blood-brain barrier (BBB), as well as lack of inhibition of most P450 cytochromes are predicted for all the compounds (Table 5).
The potential protein targets for the synthesized compounds were predicted using the new GalaxySagittarius protein-ligand docking protocol [63] based on the GalaxyWeb web server [64, 65]. The geometry and minimum energy optimized 3D structures of compounds $\mathbf{2 , 5}$, and $\mathbf{6}$ were generated using the ORCA 4.2 software package $[26,27]$. Docking using the GalaxySagittarius protocol was performed in the Binding compatability prediction and Re-ranking using docking modes. Table 6 shows the docking results compounds 2,5 , and $\mathbf{6}$ for 10 target-ligand complexes with the minimal free binding energies $\Delta G_{\text {bind }}$ and the best estimates for the protein-ligand interaction. The predicted protein targets are specified using the ID identifiers in the Protein Data Bank (PDB) and the UniProt database.

As we can see from Table 6, compounds $\mathbf{2}, \mathbf{5}$, and $\mathbf{6}$ show affinity to a wide range of proteins. In particular, the compounds are predicted to be the most affine urokinase plasminogen activator (uPA, PDB ID 1c5z, UniProt ID P00749) (Fig. 5), BRPF1 protein (PDB ID 5eww, UniProt ID P55201), and bromodomain-containing 
Table 6. Predicted protein-ligand interactions for compounds 2, 5, and $\mathbf{6}$

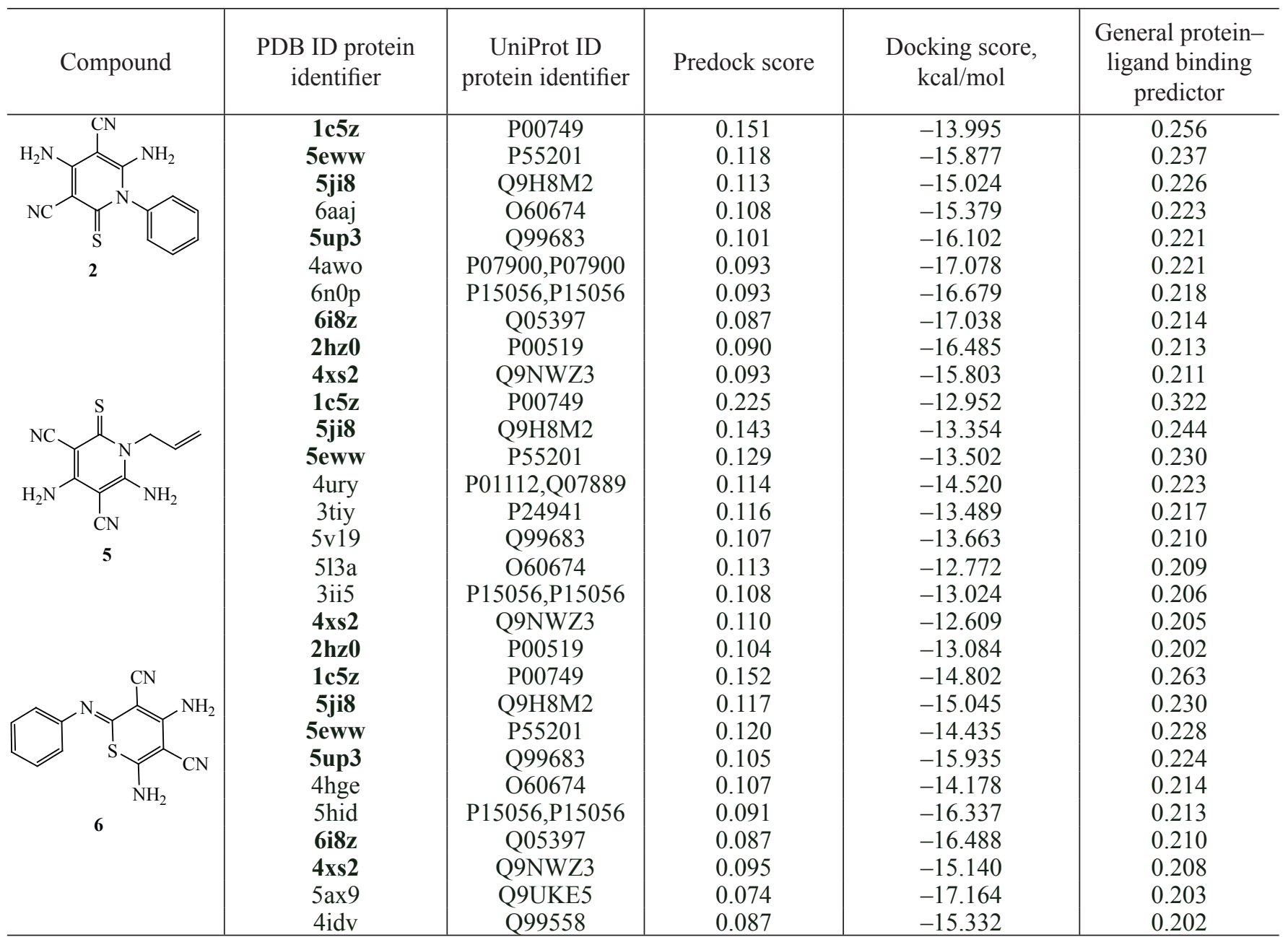

protein 9 BRD9 (PDB ID 5ji8, UniProt ID Q9H8M2), which regulates the apoptosis signal to kinase 1 ASK1/MAP3K (PDB ID 5up3, UniProt ID Q99683) and a number of other targets. Considering the important role of uPA [66] and BRD9 [67] in oncogenic processes and of ASK1/MAP3K protein kinases in the immune response [68], the synthesized compounds can be considered as inhibitors potentially useful for treating various forms of cancer, neurodegenerative processes, rheumatoid arthritis, etc. In general, the results of the study allow us to conclude the following. The reaction of malononitrile dimer with isothiocyanates can take two different paths to form 4,6-diamino-2-thioxo-1,2-dihydropyridine-3,5dicarbonitrile or 4,6-diamino-2-(phenylamino)- $2 \mathrm{H}$ thiopyran-3,5-dicarbonitrile. It should be noted that the formation of pyrimidine derivatives, reported in [9], has not been confirmed. Quantum-chemical calculations established that 2-iminothiopyrans and 2-thioxopyridines are formed under kinetically and thermodynamically controlled conditions, respectively. In the case of phenyl isothiocyanate, the reaction is regiocontrolled, and can be directed, by changing conditions, to the exclusive formation of a derivative of 2-(phenylimino)thiopyran or 2-thioxo-1-phenylpyridine. The predictive analysis of biological activity provide evidence showing that the synthesized compounds hold promise as potential pharmaceuticals.

\section{EXPERIMENTAL}

The IR spectra were obtained on a Bruker Vertex 70 spectrophotometer equipped with an ATR unit with a diamond crystal, accuracy $\pm 4 \mathrm{~cm}^{-1}$. The NMR spectra were recorded on a Bruker Avance III HD $400 \mathrm{MHz}$ instrument $\left(400.17 \mathrm{MHz}\right.$ for ${ }^{1} \mathrm{H}$ and $100.63 \mathrm{MHz}$ for 


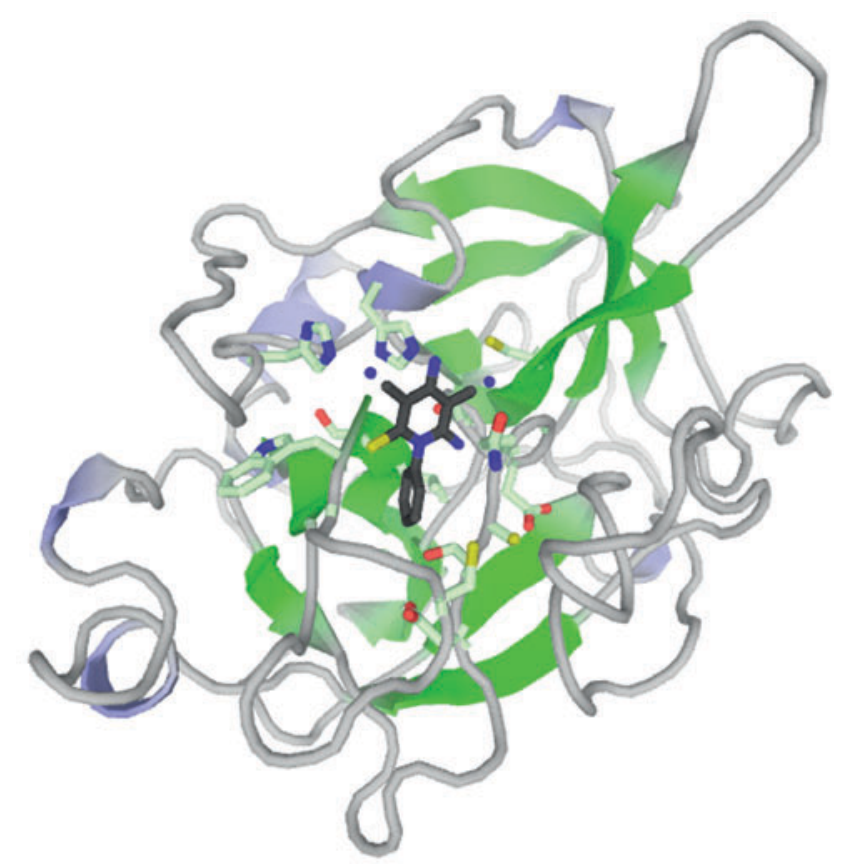

Fig. 5. Predicted structure of the protein-ligand complex of compound $\mathbf{2}$ and urokinase plasminogen activator (uPA, PDB ID 1c5z) (obtained with the GalaxySagittarius protocol).

${ }^{13} \mathrm{C}$ ) in DMSO- $d_{6}$; the residual solvent signals were used reference. The purity of the synthesized compounds was controlled by TLC on Sorbfil-A plates (Imid, Krasnodar), eluent acetone-hexane (1: 1), visualization by exposure to iodine vapor and UV light.

Malononitrile dimer $\mathbf{1}$ was prepared according to Mittelbach [1]. Malononitrile dimer potassium salt 8 was prepared by the same procedure (yield 75-90\%) but without final acidification, and the product was reacted without additional purification. Pyridine was dried over $\mathrm{KOH}$.

4,6-Diamino-1-phenyl-2-thioxo-1,2-dihydropyridine-3,5-dicarbonitrile (2). a. Synthesis from malononitrile dimer 1 in the presence of $E t_{3} N$. Triethylamine (1.05-1.6 mL, 7.57-11.35 mmol), was added to a stirred suspension of malononitrile dimer 1 ( $1.0 \mathrm{~g}, 7.57 \mathrm{mmol})$ in $15 \mathrm{~mL}$ of $96 \%$ ethanol. The mixture was stirred for $3-$ 5 min until it homogenized completely or partially, after which PhNCS (0.91 mL, $7.57 \mathrm{mmol}$ ) was added. In about 5-10 min, a yellow precipitate started to form, and within 3-4 h the mixture thickened completely. It was allowed to stand for $24 \mathrm{~h}$, after which the precipitate was filtered off, refluxed for $2 \mathrm{~min}$ in ethanol, filtered off, and washed with warm EtOH. Yield 1.70-1.86 g (84-92\%), yellow powder, $\mathrm{mp}>300^{\circ} \mathrm{C}\left\{\mathrm{mp} 250-252^{\circ} \mathrm{C}(\mathrm{AcOH})[5]\right\}$. IR spectrum, $v, \mathrm{~cm}^{-1}: 3456 \mathrm{w}, 3414 \mathrm{w}, 3367 \mathrm{~m}, 3336 \mathrm{~m}$,
$3302 \mathrm{~s}, 3211 \mathrm{~s}$, br $(\mathrm{N}-\mathrm{H}), 2206 \mathrm{~s}(\mathrm{C} \equiv \mathrm{N}), 1348 \mathrm{~s}, 1180 \mathrm{~m}$ $(\mathrm{C}=\mathrm{S}) .{ }^{1} \mathrm{H}$ NMR spectrum, $\delta$, ppm: 7.19-7.21 m(2H, $\mathrm{H}^{2}$, $\left.\mathrm{H}^{6}, \mathrm{Ph}\right), 7.31$ br. s $\left(4 \mathrm{H}, \mathrm{NH}_{2}\right), 7.43-7.53 \mathrm{~m}\left(3 \mathrm{H}, \mathrm{H}^{3}-\mathrm{H}^{5}\right.$, $\mathrm{Ph}){ }^{13} \mathrm{C}$ NMR spectrum (DEPTQ), $\delta_{\mathrm{C}}, \mathrm{ppm}: 67.3\left(\mathrm{C}^{5}\right)$, $88.1\left(\mathrm{C}^{3}\right), 114.5(\mathrm{C} \equiv \mathrm{N}), 116.9(\mathrm{C} \equiv \mathrm{N}), 129.1 *\left(\mathrm{C}^{2} \mathrm{H} \mathrm{C}^{6} \mathrm{H}\right.$ $\mathrm{Ph}), 129.5^{*}\left(\mathrm{C}^{4} \mathrm{H} \mathrm{Ph}\right), 130.1^{*}\left(\mathrm{C}^{3} \mathrm{H} \mathrm{C} \mathrm{C}^{5} \mathrm{H} \mathrm{Ph}\right), 137.7\left(\mathrm{C}^{1}\right.$ $\mathrm{Ph}), 155.6\left(\mathrm{C}^{4}\right.$ or $\left.\mathrm{C}^{6}\right), 155.9\left(\mathrm{C}^{6}\right.$ or $\left.\mathrm{C}^{4}\right), 181.0(\mathrm{C}=\mathrm{S})$. Here and hereinafter, the asterisk marks the out-of-phase signals. Found, \%: C 58.44; H 3.46; N 26.13. $\mathrm{C}_{13} \mathrm{H}_{9} \mathrm{~N}_{5} \mathrm{~S}$. Calculated, \%: 58.41; H 3.39; N 26.20. M 267.31.

b. Synthesis from malononitrile dimer 1 in boiling pyridine. Compound $\mathbf{2}$ was prepared by the procedure in [9], described as a method of synthesis of 6-amino-1phenyl-2-thioxo-1,2,3,4-tetrahydropyrimidin-4-ylidene)malononitrile. A mixture of PhNCS $(1.2 \mathrm{~mL}, 0.01 \mathrm{~mol})$ and malononitrile dimer $1(1.32 \mathrm{~g}, 0.01 \mathrm{~mol})$ in $30 \mathrm{~mL}$ of anhydrous pyridine was heated under reflux for $2 \mathrm{~h}$ and then cooled. The resulting dark blue solution was poured onto ice, acidified with $\mathrm{HCl}$ to $\mathrm{pH} 2$, and was allowed to stand in a refrigerator at $4^{\circ} \mathrm{C}$ for $24 \mathrm{~h}$. The yellow precipitate that formed was filtered off, washed with water and $\mathrm{EtOH}$, and refluxed for 3-5 min in $\mathrm{EtOH}$ for purification. The yellow-orange precipitate was filtered off to obtain 2-thioxopyridine 2 . Yield $48 \%, \mathrm{mp}>300^{\circ} \mathrm{C}$. The spectral characteristics are the same as above.

1-Allyl-4,6-diamino-2-thioxo-1,2-dihydropyridine3,5-dicarbonitrile (5). a. Synthesis from malononitrile dimer 1. Triethylamine (1.05-1.6 mL, 7.57-11.35 mmol), was added to a stirred suspension of malononitrile dimer 1 (1.0 g, $7.57 \mathrm{mmol})$ in $15 \mathrm{~mL}$ of $96 \%$ ethanol. The mixture was stirred until homogeneous, after which allyl isothiocyanate $(0.75 \mathrm{~mL}, 7.66 \mathrm{mmol})$ was added. The resulting mixture was stirred for $2 \mathrm{~h}$ and then left to stand for $24 \mathrm{~h}$ to let it to crystallize completely. The precipitate was filtered off and washed with $\mathrm{EtOH}$. Yield 1.00-1.10 g (58-73\%), colorless needle-like crystals, decomp. point $240^{\circ} \mathrm{C}$. IR spectrum, $v, \mathrm{~cm}^{-1}: 3454 \mathrm{w}$, 3365 w, 3306 s, 3213 br. s (N-H), 2204 s $(\mathrm{C} \equiv \mathrm{N}), 1344 \mathrm{~s}$, $1190 \mathrm{~m}(\mathrm{C}=\mathrm{S}) .{ }^{1} \mathrm{H}$ NMR spectrum, $\delta$, ppm: $4.95 \mathrm{~d} . \mathrm{d}(1 \mathrm{H}$, trans- $\left.\mathrm{CH}_{2},{ }^{3} \mathrm{~J} 17.4,{ }^{2} \mathrm{~J} 1.2 \mathrm{~Hz}\right), 5.09 \mathrm{~d} . \mathrm{d}\left(1 \mathrm{H}\right.$, cis $=\mathrm{CH}_{2}$, $\left.{ }^{3} J 10.5,{ }^{2} J 1.2 \mathrm{~Hz}\right), 5.28$ br. s $\left(2 \mathrm{H}, \mathrm{NCH}_{2}\right), 5.71-5.81 \mathrm{~m}$ $\left(\mathrm{CH}_{2} \mathrm{C} \underline{\mathrm{H}}=\mathrm{CH}_{2}\right), 7.20$ br. s $\left(2 \mathrm{H}, \mathrm{C}^{4} \mathrm{NH}_{2}\right), 7.97$ br. s $(2 \mathrm{H}$, $\left.\mathrm{C}^{6} \mathrm{NH}_{2}\right) .{ }^{13} \mathrm{C}$ NMR spectrum (DEPTQ), $\delta_{\mathrm{C}}, \mathrm{ppm}: 48.7$ $\left(\mathrm{NCH}_{2}\right), 67.4\left(\mathrm{C}^{5}\right), 87.7\left(\mathrm{C}^{3}\right), 114.5(\mathrm{C} \equiv \mathrm{N}), 115.7\left(=\mathrm{CH}_{2}\right)$, $117.1(\mathrm{C} \equiv \mathrm{N}), 130.6^{*}\left(\mathrm{CH}_{2} \underline{\mathrm{C}} \mathrm{H}=\mathrm{CH}_{2}\right), 154.9\left(\mathrm{C}^{4}\right.$ or $\left.\mathrm{C}^{6}\right)$, $155.2\left(\mathrm{C}^{6}\right.$ or $\left.\mathrm{C}^{4}\right), 180.0(\mathrm{C}=\mathrm{S})$. Found, \%: C 51.94; $\mathrm{H}$ 3.97; N 30.23. $\mathrm{C}_{10} \mathrm{H}_{9} \mathrm{~N}_{5}$ S. Calculated, \%: 51.93; H 3.92; N 30.28. $M$ 231.28. 
b. Synthesis from malononitrile dimer potassium salt 8. Allyl isothiocyanate $(0.5 \mathrm{~mL}, 5.09 \mathrm{mmol})$ and then $2 \mathrm{~mL}$ of water were added to a stirred suspension of $0.87 \mathrm{~g}(5.09 \mathrm{mmol})$ of salt 8 in $10 \mathrm{~mL} \mathrm{EtOH}$. A slight exotherm developed, and the mixture homogenized to form a tea-colored solution. A day after, a crystalline precipitate began to slowly form. In 3 days, the pale pink crystals were filtered off and washed with EtOH and petroleum ether. The product was spectrally identical to compound $\mathbf{5}$ prepared as described above. Yield $329 \mathrm{mg}(28 \%)$. Attempted isolation of an additional amount of the product by addition water or acid to the mother liquor failed.

4,6-Diamino-2-(phenylimino)-2H-thiopyran-3,5dicarbonitrile (6). a. Synthesis from malononitrile dimer in pyridine. A mixture of PhNCS $(1.2 \mathrm{~mL}, 0.01 \mathrm{~mol})$ and malononitrile dimer 1 (1.32 g, $0.01 \mathrm{~mol})$ in $30 \mathrm{~mL}$ of anhydrous pyridine was allowed to stand for $24 \mathrm{~h}$ at $25^{\circ} \mathrm{C}$ and then refluxed for $2 \mathrm{~h}$ and cooled down. The resulting dark solution was poured onto ice, acidified to $\mathrm{pH} 2$ with $\mathrm{HCl}$, and allowed to stand in a refrigerator for $24 \mathrm{~h}$ at $4^{\circ} \mathrm{C}$. The precipitate was filtered off, washed with $\mathrm{EtOH}$, and refluxed for 3-5 min in EtOH for purification. The beige precipitate was filtered off to obtain $0.20 \mathrm{~g}(8 \%)$ of compound $\mathbf{6}, \mathrm{mp}>300^{\circ} \mathrm{C}\left\{\mathrm{mp} 225^{\circ} \mathrm{C}(\mathrm{EtOH})[9]\right\}$. IR spectrum, $v, \mathrm{~cm}^{-1}: 3427 \mathrm{w}, 3410 \mathrm{w}, 3371 \mathrm{~m}, 3352 \mathrm{~m}$, 3329 m, 3234 s, ш $(\mathrm{N}-\mathrm{H}), 2212 \mathrm{c}(\mathrm{C} \equiv \mathrm{N}), 1643 \mathrm{~m}(\mathrm{C}=\mathrm{N})$. ${ }^{1} \mathrm{H}$ NMR spectrum, $\delta$, ppm: 7.11 br. s $\left(2 \mathrm{H}, \mathrm{C}^{4} \mathrm{NH}_{2}\right)$, 7.18 br. s $\left(2 \mathrm{H}, \mathrm{C}^{6} \mathrm{NH}_{2}\right), 7.24-7.27 \mathrm{~m}\left(2 \mathrm{H}, \mathrm{H}^{2}, \mathrm{H}^{6}\right.$, $\mathrm{Ph}), 7.48-7.54 \mathrm{~m}\left(3 \mathrm{H}, \mathrm{H}^{3} \mathrm{H}^{5}, \mathrm{Ph}\right) .{ }^{13} \mathrm{C}$ NMR spectrum (DEPTQ), $\delta_{\mathrm{C}}$, ppm: $62.4\left(\mathrm{C}^{5}\right), 69.4\left(\mathrm{C}^{3}\right), 115.2(\mathrm{C} \equiv \mathrm{N})$, $116.6(\mathrm{C} \equiv \mathrm{N}), 129.3^{*}\left(\mathrm{C}^{2} \mathrm{H}, \mathrm{C}^{6} \mathrm{H}, \mathrm{Ph}\right), 129.5^{*}\left(\mathrm{C}^{4} \mathrm{H}, \mathrm{Ph}\right)$, 130.0* $\left(\mathrm{C}^{3} \mathrm{H}, \mathrm{C}^{5} \mathrm{H}, \mathrm{Ph}\right), 134.1\left(\mathrm{C}^{1}, \mathrm{Ph}\right), 156.7\left(\mathrm{C}^{6}\right), 159.3$ $\left(\mathrm{C}^{4}\right), 160.4\left(\mathrm{C}^{2}\right)$. Found, \%: C 58.40; H 3.50; N 26.15. $\mathrm{C}_{13} \mathrm{H}_{9} \mathrm{~N}_{5}$ S. Calculated, \%: 58.41; H 3.39; N 26.20. $M$ 267.31.

b. Synthesis of malononitrile dimer potassium salt $\mathbf{8}$. Phenyl isothiocyanate $(3 \mathrm{~mL}, 0.0526 \mathrm{~mol})$, was added to a stirred suspension of salt $8(9.0 \mathrm{~g}, 0.0526 \mathrm{~mol})$ in $135 \mathrm{~mL}$ of $96 \%$ ethanol.

Therewith, salt 8 quickly dissolved, and a yellow solution was formed. After $\sim 2 \mathrm{~h}$, a precipitate started to form. The mixture was stirred without heating for another $24 \mathrm{~h}$. White powder of 2-iminothiopyran 6 was filtered off, washed with EtOH. Yield $11.57 \mathrm{~g}(82 \%)$. The product is spectrally identical to compound $\mathbf{6}$ obtained as described above.

\section{AUTHOR INFORMATION}

V.V. Dotsenko, ORCID: http://orcid.org/0000-0001-71630497

A.V. Bespalov, ORCID: http://orcid.org/0000-0002-98299674

A.A. Russkikh, ORCID: http://orcid.org/0000-0001-93549470

V.K. Kindop, ORCID: http://orcid.org/0000-0002-90059668

N.A. Aksenov, ORCID: http://orcid.org/0000-0002-71259066

I.V. Aksenova, ORCID: http://orcid.org/0000-0002-80831407

S.V. Shcherbakov, ORCID: http://orcid.org/0000-00033828-6641

S.N . Ovcharov, ORCID: http://orcid.org/0000-0002-46386098

\section{FUNDING}

This work financially supported by the Kuban Science Foundation (project no. MFI-20.1-26/20, application no. MFI20.1/45) and the Ministry of Education and Science of the Russian Federation (topic 0795-2020-0031) and performed using the equipment of the Diagnostics of the Structure and Properties of Nanomaterials Scientific and Educational Center, Kuban State University.

\section{CONFLICT OF INTEREST}

No conflict of interest was declared by the authors.

\section{OPEN ACCESS}

This article is licensed under a Creative Commons Attribution 4.0 International License, which permits use, sharing, adaptation, distribution and reproduction in any medium or format, as long as you give appropriate credit to the original author(s) and the source, provide a link to the Creative Commons license, and indicate if changes were made. The images or other third party material in this article are included in the article's Creative Commons license, unless indicated otherwise in a credit line to the material. If material is not included in the article's Creative Commons license and your intended use is not permitted by statutory regulation or exceeds the permitted use, you will need to obtain permission directly from the copyright holder. To view a copy of this license, visit http://creativecommons.org/licenses/by/4.0/.

\section{SUPPLEMENTARY INFORMATION}

The online version contains supplementary material available at https://doi.org/10.1134/S1070363221060013 


\section{REFERENCES}

1. Mittelbach, M., Monatsh. Chem., 1985, vol. 116, no. 5, p. 689. https://doi.org/10.1007/BF00798796

2. Dotsenko, V.V., Krivokolysko, S.G., and Semenova, A.M., Chem. Heterocycl. Compd., 2018, vol. 54, no. 11, p. 989. https://doi.org/10.1007/s10593-018-2383-y

3. Shaabani, A. and Hooshmand, S.E., Mol. Divers., 2018, vol. 22 , no. 1 , p. 207. https://doi.org/10.1007/s11030-017-9807-y

4. Alekseeva, A.Yu. and Bardasov, I.N., Chem. Heterocycl. Compd., 2018, vol. 54, no. 7, p. 689. https://doi.org/10.1007/s10593-018-2332-9

5. Eldin, A.M.S., Phosphorus, Sulfur, Silicon, Relat. Elem., 2003, vol. 178, no. 10, p. 2215. https://doi.org/10.1080/713744561

6. El-Taweel, F.M., Elagamey, A.A., El-Kenawy, A.A., and Waly, M.A., Phosphorus, Sulfur, Silicon, Relat. Elem., 2001, vol. 176, no. 1, p. 215. https://doi.org/10.1080/10426500108055120

7. Mohareb, R.M., Sherif, S.M., and Samy, A.M., Phosphorus, Sulfur, Silicon, Relat. Elem., 1995, vol. 101, nos. 1-4, p. 57. https://doi.org/10.1080/10426509508042499

8. Mohareb, R.M., Monatsh. Chem., 1992, vol. 123, no. 4, p. 341 . https://doi.org/10.1007/BF00810946

9. Abdel-Latif, E., Mustafa, H.M., Etman, H.A., and Fadda, A.A., Russ. J. Org. Chem., 2007, vol. 43, no. 3, p. 443. https://doi.org/10.1134/S1070428007030219

10. Dotsenko, V.V., Ismiev, A.I., Khrustaleva, A.N., Frolov, K.A., Krivokolysko, S.G., Chigorina, E.A., Snizhko, A.P., Gromenko, V.M., Bushmarinov, I.S., Askerov, R.K., Pekhtereva, T.M., Suykov, S.Yu., Papayanina, E.S., Mazepa, A.V., and Magerramov, A.M., Chem. Heterocycl. Compd., 2016, vol. 52, no. 7, p. 473. https://doi.org/10.1007/s10593-016-1918-3

11. Semenova, A.M., Oganesyan, R.V., Dotsenko, V.V., Chigorina, E.A., Aksenov, N.A., Aksenova, I.V., and Netreba, E.E., Russ. J. Gen. Chem., 2019, vol. 89, no. 1, p. 19. https://doi.org/10.1134/S1070363219010043

12. Dotsenko, V.V., Krivokolysko, S.G., and Semenova, A.M., Chem. Heterocycl. Compd., 2018, vol. 54, no. 11, p. 989. https://doi.org/10.1007/s10593-018-2383-y

13. Bakhite, E.A.-G., Phosphorus, Sulfur, Silicon, Relat. Elem., 2003, vol. 178, p. 929.

https://doi.org/10.1080/10426500390208820

14. Paronikyan, Ye.G., Arutyunyan, A.S., and Dashyan, Sh.Sh., Khim. Zh. Arm., 2017, vol. 70, nos. 1-2, p. 179.

15. Dotsenko, V.V., Buryi, D.S., Lukina, D.Yu., and Krivokolysko, S.G., Russ. Chem. Bull., 2020, vol. 69, no. 10 , p. 1829 . https://doi.org/10.1007/s11172-020-2969-2

16. Sajadikhah S.S. and Marandi, G., Chem. Heterocycl. Compd., 2019, p. 1171.

https://doi.org/10.1007/s10593-019-02596-1
17. Akhmetova, V.R., Nadyrgulova, G.R., Niatshina, Z.T., and Dzhemilev, U.M., Chem. Heterocycl. Compd., 2009, vol. 45, no. 10, p. 1155. https://doi.org/10.1007/s10593-010-0403-7

18. Akhmetova, V.R. and Rakhimova, E.B., Russ. J. Org. Chem., 2014, vol. 50, no. 12, p. 1711. https://doi.org/10.1134/S107042801412001X

19. Dotsenko, V.V., Frolov, K.A., and Krivokolysko, S.G., Chem. Heterocycl. Compd., 2015, vol. 51, no. 2, p. 109. https://doi.org/10.1007/s10593-015-1668-7

20. Dotsenko, V.V., Frolov, K.A., Chigorina, E.A., Khrustaleva, A.N., Bibik, E.Yu., and Krivokolysko, S.G., Russ. Chem. Bull., 2019, vol. 68, no. 4, p. 691. https://doi.org/10.1007/s11172-019-2476-5

21. Dotsenko, V.V., Krivokolysko, S.G., and Chigorina, E.A., Russ. J. Gen. Chem. 2020, vol. 90, no. 4, p. 590. https://doi.org/10.1134/S1070363220040052

22. El-Sayed, A.M. and Abdel-Ghany, H., J. Heterocycl. Chem., 2000, vol. 37, no. 5, p. 1233. https://doi.org/10.1002/jhet.5570370534

23. Gewald, K., Buchwalder, M., and Peukert, M., J. Prakt. Chem., 1973, vol. 315, no. 4, p. 679. https://doi.org/10.1002/prac.19733150413

24. Bogdanowicz-Szwed, K., Monatsh. Chem., 1982, vol. 113, no. 5, p. 583 . https://doi.org/10.1007/BF00800265

25. Takeshima, T., Yokoyama, M., Fukada, N., and Akano, M., J. Org. Chem., 1970, vol. 35, no. 7, p. 2438. https://doi.org/10.1021/jo00832a085

26. Neese, F., WIREs Comput. Mol. Sci., 2011, vol. 2, p. 73. https://doi.org/10.1002/wcms.81

27. Neese F., WIREs Comput. Mol. Sci., 2017, vol. 8, p. e1327. https://doi.org/10.1002/wcms.1327

28. Becke, A.D., Phys. Rev. A, 1988, vol. 38, p. 3098. https://doi.org/10.1103/PhysRevA.38.3098

29. Lee, C., Yang, W., and Parr, R.G., Phys. Rev. B, 1988, vol. 37, p. 785 . https://doi.org/10.1103/PhysRevB.37.785

30. Grimme, S., Antony, J., Ehrlich, S., and Krieg, H., J. Chem. Phys., 2010, vol. 132, p. 154104. https://doi.org/10.1063/1.3382344

31. Goerigk, L. and Grimme, S., Phys. Chem. Chem. Phys., 2011, vol. 13, p. 6670. https://doi.org/10.1039/C0CP02984J

32. Andersson, M.P. and Uvdal, P., J. Phys. Chem. A, 2005, vol. 109, p. 2937. https://doi.org/10.1021/jp045733a

33. Allouche, A.-R., J. Comput. Chem., 2011, vol. 32, p. 174. https://doi.org/10.1002/jcc.21600.

34. Brandenburg, J.G., Bannwarth, C., Hansen, A., and Grimme, S., J. Chem. Phys., 2018, vol. 148, p. 064104. https://doi.org/10.1063/1.5012601

35. Caldeweyher, E. and Brandenburg, J.G., J. Phys. Condens. Matter, 2018, vol. 30, p. 213001. https://doi.org/10.1088/1361-648X/aabcfb

36. Grimme, S., Ehrlich, S., and Goerigk, L., J. Comput. Chem., 2011, vol. 32, p. 1456. https://doi.org/10.1002/jcc.21759 
37. Tomasi, J., Mennucci, B., and Cammi, R., Chem. Rev., 2005, vol. 105, p. 2999. https://doi.org/10.1021/cr9904009

38. Litvinov, V.P., Rodinovskaya, L.A., Sharanin, Yu.A., Shestopalov, A.M., and Senning, A., J. Sulfur Chem., 1992, vol. 13, no. 1, p. 1. https://doi.org/10.1080/01961779208048951

39. Litvinov, V.P., Phosphorus, Sulfur, Silicon, Relat. Elem., 1993, vol. 74, no. 1, p. 139. https://doi.org/10.1080/10426509308038105

40. Litvinov, V.P., Russ. Chem. Bull., 1998, vol. 47, no. 11, p 2053. https://doi.org/10.1007/BF02494257

41. Litvinov, V.P., Krivokolysko, S.G., and Dyachenko, V.D., Chem. Heterocycl. Compd., 1999, vol. 35, no. 5, p. 509. https://doi.org/10.1007/BF02324634

42. Litvinov, V.P., Russ. Chem. Rev., 2006, vol. 75, no. 7, p. 577. https://doi.org/10.1070/RC2006v075n07ABEH003619

43. Attia, A.M., Khodair, A.I., Gendy, E.A., El-Magd, M.A., and Elshaier, Y.A.M.M., Lett. Drug Design Discov., 2020, vol. 17 , no. 2, p. 124. https://doi.org/10.2174/1570180816666190220123547

44. Catarzi, D., Varano, F., Varani, K., Vincenzi, F., Pasquini, S., Dal Ben, D., Volpini, R., and Colotta, V., Pharmaceuticals, 2019, vol. 12, no. 4, p. 159. https://doi.org/10.3390/ph12040159

45. Schweda, S.I., Alder, A., Gilberger, T., and Kunick, C., Molecules, 2020, vol. 25, no. 14, p. 3187. https://doi.org/10.3390/molecules25143187

46. Grigor'ev, A.A., Shtyrlin, N.V., Gabbasova, R.R., Zeldi, M.I., Grishaev, D. Yu., Gnezdilov, O.I., Balakin, K.V., Nasakin, O.E., and Shtyrlin, Y.G., Synth. Commun., 2018, vol. 48, no. 17, p. 2288. https://doi.org/10.1080/00397911.2018.1501487

47. Betti, M., Catarzi, D., Varano, F., Falsini, M., Varani, K., Vincenzi, F., Dal Ben, D., Lambertucci, C., and Colotta, V., Eur. J. Med. Chem., 2018, vol. 150, p. 127. https://doi.org/10.1016/j.ejmech.2018.02.081

48. Fugel, W., Oberholzer, A.E., Gschloessl, B., Dzikowski, R., Pressburger, N., Preu, L., Pearl, L.H., Baratte, B., Ratin, M., Okun, I., Doerig, C., Kruggel, S., Lemcke, T., Meijer, L., and Kunick, C., J. Med. Chem., 2013, vol. 56, no. 1, p. 264. https://doi.org/10.1021/jm301575n

49. Sanchez, M.I., de Vries, L.E., Lehmann, C., Lee, J.T., Ang, K.K., Wilson, C., Chen, S., Arkin, M.R., Bogyo, M., Deu, E., PloS One, 2019, vol. 14, no. 12, article no. e0226270.

https://doi.org/10.1371/journal.pone.0226270

50. Zhou, P. and Warren, J.D., WO Patent 2014031759, 2014.

51. Whitten, J.P., Pei, Y., Stauderman, K.A., and Roos, J., US Patent 2010087415, 2010.

52. Lipinski, C.A., Lombardo, F., Dominy, B.W., and Feeney, P.J., Adv. Drug. Delivery Rev., 1997, vol. 23, nos. 1-3, p. 4. https://doi.org/10.1016/S0169-409X(96)00423-1

53. Lipinski, C.A., Drug Discov. Today: Technol., 2004, vol. 1 , no. 4 , p. 337.

https://doi.org/10.1016/j.ddtec.2004.11.007
54. Lipinski, C.A., Lombardo, F., Dominy, B.W., and Feeney, P.J., Adv. Drug. Delivery Rev., 2012, vol. 64, Suppl. p. 4. https://doi.org/10.1016/j.addr.2012.09.019.

55. Sander, T., OSIRIS Property Explorer, Idorsia Pharmaceuticals, Switzerland. http://www.organic-chemistry.org/prog/peo/.

56. PASS Online. Laboratory for Structure-Function Based Drug Design, Institute of Biomedical Chemistry (IBMC), Moscow, Russia.

http://www.pharmaexpert.ru/passonline/predict.php.

57. Filimonov, D.A., Lagunin, A.A., Gloriozova, T.A., Rudik, A.V., Druzhilovskii, D.S., Pogodin, P.V., and Poroikov, V.V., Chem. Heterocycl. Compd., 2014, vol. 50 , no. 3 , p. 444 . https://doi.org/10.1007/s10593-014-1496-1

58. Way2Drug. antiBac-Pred. Laboratory for StructureFunction Based Drug Design, Institute of Biomedical Chemistry (IBMC), Moscow, Russia. http://way2drug.com/antibac/.

59. Daina, A., Michielin, O., and Zoete, V., Sci. Rep., 2017, vol. 7, article no. 42717. https://doi.org/10.1038/srep42717

60. Gfeller, D., Grosdidier, A., Wirth, M., Daina, A., Michielin, O., and Zoete, V., Nucl. Acids Res., 2014, vol. 42, no. W1, p. W32. https://doi.org/10.1093/nar/gku293

61. Lagunin, A., Zakharov, A., Filimonov, D., and Poroikov, V., Mol. Informatics, 2011, vol. 30, nos. 2-3, p. 241. https://doi.org/10.1002/minf.201000151

62. GUSAR Online. Laboratory for Structure-Function Based Drug Design, Institute of Biomedical Chemistry (IBMC), Moscow, Russia.

http://www.way2drug.com/gusar/references.html.

63. Yang, J., Kwon, S., Bae, S.H., Park, K.M., Yoon, C., Lee, J.H., and Seok, C., J. Chem. Inf. Model., 2020, vol. 60, no. 6, p. 3246. https://doi.org/10.1021/acs.jcim.0c00104

64. GalaxyWEB. A web server for protein structure prediction, refinement, and related methods. Computational Biology Lab, Department of Chemistry, Seoul National University, S. Korea. http://galaxy.seoklab.org/index.html

65. Ko, J., Park, H., Heo, L., and Seok, C., Nucleic Acids Res., 2012, vol. 40, no. W1, p. W294. https://doi.org/10.1093/nar/gks493

66. Katz, B.A., Mackman, R., Luong, C., Radika, K., Martelli, A., Sprengeler, P.A., Wang, J., Chan, H., and Wong, L., Chem. Biol., 2000, vol. 7, no. 4, p. 299. https://doi.org/10.1016/s1074-5521(00)00104-6

67. Clark, P.G., Vieira, L.C., Tallant, C., Fedorov, O., Singleton, D.C., Rogers, C.M., Monteiro, O.P., Bennett, J.M., Baronio, R., Müller, S., Daniels, D.L., Méndez, J., Knapp, S., Brennan, P.E., and Dixon, D.J., Angew. Chem. Int. Ed., 2015, vol. 54, no. 21, p. 6217. https://doi.org/10.1002/anie.201501394

68. Hayakawa, T., Matsuzawa, A., Noguchi, T., Takeda, K., and Ichijo, H., Microb. Infect., 2006, vol. 8, no. 4, p. 1098. https://doi.org/10.1016/j.micinf.2005.12.001 